\title{
Internationalization of the RMB and Historical Precedents
}

\author{
Jeffrey Frankel
}

Harvard University

\section{Introduction}

The possibility that the renminbi may soon join the ranks of international currencies has generated much excitement. This paper looks to history for help in evaluating the factors determining its prospects. The three best precedents in the twentieth century were the rise of the dollar from 1913 to 1945, the rise of the Deutsche mark from 1973 to 1990, and the rise of the yen from 1984 to 1991. The fundamental determinants of international currency status are economic size, confidence in the currency, and depth of financial markets. The new view is that, once these three factors are in place, internationalization of the currency can proceed quite rapidly. Thus some observers have recently forecast that the RMB may even challenge the dollar within a decade. But they underestimate the importance of the third criterion, the depth of financial markets. In principle, the Chinese government could decide to create that depth, which would require accepting an open capital account, diminished control over the domestic allocation of credit, and a flexible exchange rate. But although the Chinese government has been actively promoting offshore use of the currency since 2010, it has not done very much to meet these requirements. Indeed, to promote internationalization as national policy would depart from the historical precedents. In all three twentieth-century cases of internationalization, popular interest in the supposed prestige of having the country's currency appear in the international listings

\footnotetext{
* Corresponding Author: Jeffrey Frankel; Kennedy School of Government, Harvard University, 79 JFK St., Cambridge MA 02138-5801, USA, 617 496-3834, Jeffrey_frankel@harvard.edu.

Acknowledgements: The author would like to thank Menzie Chinn, Sebastian Mallaby, and Cynthia Mei Balloch. This paper draws in part on a November 2011 CGS/IIGG working paper 17, "Historical Precedents for Internationalization of the RMB," among other papers for a Council on Foreign Relations project.
} 
was scant, and businessmen feared that the currency would strengthen and damage their export competitiveness. Probably China, likewise, is not yet fully ready to open its domestic financial markets and let the currency appreciate, so the renminbi will not be challenging the dollar for a long time.

We begin, however, by asking: What is international currency status, and why does it matter?

\section{A. Definitions}

An international currency is one that is used outside its home country. ${ }^{1}$ Reserve currency status is the main measure used in this paper, but it is just one of a number of possible measures of international use. The others can be neatly summarized by means of Table 1 , a simple $2 \times 3$ table adapted from versions originally introduced by Cohen (1971) and Kenen (1983). The classic three functions of money domestically - store of value, medium of exchange, and unit of account - can be transferred to the level of international money. Under each function are important examples of how government authorities and private actors sometimes choose to use a major international currency other than their own. The main focus of this paper appears in the first cell, the decision of central banks to hold their reserves in the form of particular currencies. But other possible criteria of an international currency also appear in the table: currency substitution (e.g., the circulation of dollar currency in Latin America and elsewhere), invoicing foreign trade and denominating international financial flows, pegs for smaller countries' currencies, and foreign exchange trading. Statistics on the various measures of international currency use are reported in an appendix.

Studies of currency internationalization often focus on reserve currency holdings for three reasons. First, annual data for all relevant currencies are available over the past forty-five years or more; the other international roles that appear in Table 1 are nowhere near as comprehensively quantifiable. Second, reserve currency holdings are most relevant to the important questions, such as whether the United States will continue to be able to finance its current account deficit. Third, the various roles of an international currency are heavily interrelated, causally and statistically.

Frankel (1992, 1995); Eichengreen and Frankel (1996), Chinn and Frankel (2007, 2008). 
Table 1. Roles of an International Currency

\begin{tabular}{|c|c|c|}
\hline Function of money & Governments & Private actors \\
\hline Store of value & International reserves & $\begin{array}{c}\text { Currency substitution } \\
\text { (private dollarization) }\end{array}$ \\
\hline Medium of exchange & $\begin{array}{c}\text { Vehicle currency for foreign } \\
\text { exchange intervention }\end{array}$ & $\begin{array}{c}\text { Invoicing trade and } \\
\text { financial transactions }\end{array}$ \\
\hline Unit of account & $\begin{array}{c}\text { Anchor for pegging local } \\
\text { currency }\end{array}$ & $\begin{array}{c}\text { Denominating trade and } \\
\text { financial transactions }\end{array}$ \\
\hline
\end{tabular}

\section{B. Should we care about International Currency Rankings?}

Is the question of international currency status important? It has fewer direct implications for the economy than the currency's exchange rate does, but it is important nevertheless. To begin with, the exchange rate and international currency status have always been causally interrelated notwithstanding some periods such as the early 1990s when they have moved in opposite directions for the dollar. But the topic has been made urgent by the question of whether international imbalances, specifically the U.S. current account deficit and Chinese current account surplus, are sustainable.

\section{Advantages of having an International Currency}

One can think of four advantages to a country of having its currency play a large role in the world:

- Convenience for the country's residents. It is certainly more convenient for a country's exporters, importers, borrowers, and lenders to be able to deal in its own currency than foreign currencies. Doing so reduces transaction costs as well as foreign exchange risks. ${ }^{2}$ The global use of the dollar, as with the global use of the English language, is a natural advantage that American businessmen tend to take for granted.

- More business for the country's banks and other financial institutions. There need be no firm connection between the currency in which banking is conducted and the nationality of the banks, or between the nationalities of savers and borrowers and the nationality of the intermediating bank. Nevertheless, it stands to reason that U.S. banks have a comparative

\footnotetext{
${ }^{2}$ Cheung, Ma, and McCauley (2010) argue that internationalization of the RMB would carry for China the advantage of sharing some of the foreign exchange risk that China runs with the rest of the world, essentially that it would reduce currency mismatch, and in this case excessive exposure to dollars on the asset side.
} 
advantage at dealing in dollars, British banks at dealing in pounds, Chinese banks at dealing in renminbi, and so on.

- Seigniorage. This is perhaps the most well-known advantage of having other countries hold one's currency. They must give up real goods and services, or ownership of the real capital stock, in order to add to the dollars that they use. We are not necessarily talking about Seigniorage narrowly defined (foreign holdings of U.S. currency, which doesn't pay interest). More important is the U.S. ability to run up huge debts denominated in its own currency at low interest rates. The United States has consistently earned more on its investments overseas than it has had to pay on its debts, a differential of about 1 percent per annum. ${ }^{3}$ Possibly this American role as the world's banker (taking short-term liquid deposits and lending long term in riskier higher-return assets) would survive the loss of the dollar as the leading international currency. But it seems possible that the loss of one would lead to the loss of the other.

- Political power and prestige. Britain's gradual loss of key currency status was simultaneous with its gradual loss of political and military preeminence. A run on the pound played an important role in the Suez crisis of 1956, for example, when Britain was forced under US pressure to abandon what was left of its imperial designs.

\section{Disadvantages of having an International Currency}

One can think of three disadvantages from the viewpoint of a key currency country. They explain why Japan and Germany were in the past reluctant to have their currencies held and used widely, and why China worries about the implications of beginning to internationalize its currency.

- Larger fluctuations in demand for the currency. It is not automatically clear that having one's currency held by a wide variety of people around the world would result in greater variability of demand. Such instability is probably more likely to follow from an increase in the degree of capital mobility, than from key currency status per se. Nevertheless, the two are related. Central banks are sometimes concerned that internationalization will make it more difficult to control the money stock. This problem need not arise if they do not intervene in the foreign exchange market. But the central bank may view letting fluctuations in demand for the currency be reflected in the exchange rate as being just as undesirable as letting them be reflected in the money supply.

- An increase in the average demand for the currency. This is the other side of Seigniorage. In

${ }^{3}$ Cline (2005). See also sources cited by Subramanian (2011, p. 5).

${ }^{4}$ E.g., Boughton (2001). 
the 1960s and 1970s, the Japanese and German governments were particularly worried about the possibility that if assets were made available to foreign residents, an inflow of capital would cause the currency to appreciate and render exporters less competitive on world markets. Again, this is also China's problem today.

- Burden of responsibility. The monetary authorities in the country of a leading international currency may be called on to take into account the effects of their actions on world markets, rather than being free to devote monetary policy solely to domestic objectives. The Federal Reserve probably cut interest rates more than it otherwise would have in the second half of 1982, and again in late 1998, in response to international debt problems in Latin America and elsewhere. At times, Argentina or others have considered officially dollarizing. Reluctance to accept any burden of responsibility, even if only implicit, explains the lack of enthusiasm from U.S. authorities.

\section{E. What determines whether a Currency is suited to International Status?}

The literature on what determines reserve currency status is fairly well-established. Three points are important:

First are fundamental determinants. A list of country-specific determining factors follows. The most important is the size of the country or region in which the currency is indigenously used, but there are others as well. Network externalities or economies of scale and scope are important. Each country is more likely to use whatever currency is used by others but the determinants of international currency use is not linear. There may be a tipping phenomenon such as if one currency were to draw even and surpass another, the derivative of reserve currency share with respect to its determining variables - the change in currency use corresponding to a given 0.01 increase in economic fundamentals - would be higher in the vicinity of 50/50 than in the vicinity of zero or in the range when the leading currency is unchallenged. In that sense, the switch happens rapidly. ${ }^{5}$ Third, in the chronological sense, however, it has usually been argued that the switch happens slowly. Whatever currency has been used in the past will continue to be used in the future. Thus inertia is great.

The literature on international currencies has identified a number of factors that determine whether a currency is suited for international currency status. ${ }^{6}$

One relates to patterns of output and trade. The currency of a country that has a large share

\footnotetext{
${ }^{5}$ As Eichengreen $(2005,2010)$ points out, counteracting the arguments about network externalities and tipping, particularly in determining the reserve currency function, is an argument in favor of multiple simultaneous international currencies or competition for the affections of investors.

${ }^{6}$ Among the relevant references are Aliber (1966); Alogoskoufis and Portes (1992); Bergsten (1975); Black (1989); Eichengreen and Frankel (1996); Eichengreen and Mathieson (2001); Frankel (1992, 1995); Kenen (1983); Krugman (1984); Kindleberger (1981); Matsuyama, Kiyotaki, and Matsui (1993); McKinnon (1969; 1979); Portes and Rey (1998); Rey (2001); Swoboda (1969); Tavlas (1993); Tavlas and Ozeki (1992).
} 
in international output, trade, and finance has a big natural advantage. The U.S. economy is still the world's largest in terms of output and trade. Alarmist fears of the early 1990s notwithstanding, it was never very likely that Japan, a country with half the population and far less land area or natural resources, would surpass the United States in sheer economic size. The euro is now the home currency to seventeen countries. Their combined economic weight is much greater than Germany alone, or Japan, and roughly equal to that of the United States. For some measures of international currency use - how often a vehicle currency is used in the invoicing and financing of international trade - other aspects of the pattern of trade may also be relevant. That much of Asia's imports are oil and other raw materials and that much of its exports go to the western hemisphere, for example, help explain why a disproportionately small share of trade is invoiced in yen or renminbi as opposed to dollars. Raw materials still tend heavily to be priced in dollars. Whenever the dollar depreciates for more than a few years, the OPEC (Organization of the Petroleum Exporting Countries) starts discussing switching to another currency of denomination. It hasn't happened yet, but it could if the dollar's primacy in other international roles were seriously challenged.

A second factor is a country's financial markets. To attain international currency status, capital and money markets in the home country must be not only open and free of controls, but also deep and well-developed. The large financial marketplaces of New York and London clearly benefit the dollar and pound relative to the euro and its predecessor, the deutschemark, as Frankfurt is still less well-developed. The Tokyo and Frankfurt financial markets have changed a lot over the last few decades but they still lag far behind New York and London as financial centers. Meanwhile, Singapore and Hong Kong have gained, and Shanghai may be next.

It is surprisingly difficult to come up with a proxy for size, depth, or development that is available for all the financial centers. We have opted to use as our primary measure data on foreign exchange turnover the respective financial centers of New York, London, Frankfurt, Tokyo, Zurich, etc. This measure differs from the turnover of currencies (dollar, pound, euro, etc.), a variable that would be much more simultaneous with the international currency status that we are trying to explain. It captures, for example, the pre-eminence of London, which continues despite the small role of the pound. This measure has the virtue of reflecting to some extent all kinds of international financial transactions (both long-term and short-term, banking and securities, bonds and equities). Moreover it is possible to patch together a data set covering the desired countries and years - though but just barely, and with increasing difficulty as one goes back through the 1970s. We have also tried an alternative proxy for the size of financial centers - the size of the countries' stock markets. As an alternative to quantity-based measures, bid-ask spreads might capture the efficiency and liquidity of various financial markets.

A third factor is confidence in the value of the currency. Even if a key currency were used only as a unit of account, a necessary qualification would be that its value not fluctuate erratically. As it is, a key currency is also used as a form in which to hold assets (firms hold working balances of the currencies in which they invoice, investors hold bonds issued internationally, 
and central banks hold currency reserves). Here confidence that the value of the currency will be stable, and particularly that it will not be inflated away in the future, is critical. The monetary authorities in Japan, Germany, and Switzerland in the 1970s established a better track record of low inflation than did the United States', which helped them attain international currency status. As recently as the 1980s, the mean and variance of the inflation rate in the United States were both higher than in those three hard-currency countries, though lower than in the United Kingdom, France, Italy, and many other countries.

Given the good U.S. inflation performance since the 1980s, this is no longer such a concern. A more important negative for the dollar is the fact that the United States is now a large-scale debtor country. Even if the Federal Reserve never succumbs to the temptations or pressures to inflate away the U.S. debt, the continuing U.S. current account deficit is always a possible source of downward pressure on the dollar. Such fears work to make dollars unattractive.

A fourth factor is network externalities. An international money, like domestic money, derives its value because others are using it. It is a classic instance of network externalities. They suggest that, even in the long run, measures of international currency use may not be linear. There may be a tipping phenomenon when one currency passes another. Furthermore, the network externalities may produce inertia. The intrinsic characteristics of a currency may be less important than the path-dependent historical equilibrium as there is an inertial bias in favor of using whatever currency has been the international currency in the past.

The analogy with language is always useful. If one sat down to design an ideal language, it would not be English. Nobody would claim that the English language is particularly wellsuited to be the world's lingua franca by virtue of its intrinsic beauty, simplicity, or utility. It is neither as elegant and euphonious as French, for example, nor as simple and logical in spelling and grammar as Spanish or Italian. Yet it is certainly the language in which citizens of different countries most often converse and do business, and increasingly do so. One chooses to use a lingua franca, as one chooses a currency, in the belief that it is the one that others are most likely to use.

The implication is that small changes in the determinants will not produce corresponding changes in the reserve currency numbers, at least not in the short run. Changes may show up only with a long lag. As noted, the pound remained an important international currency even after the United Kingdom lost its position as an economic superpower early in the century. In the present context, the inertial bias favors the continued central role of the dollar.

Another aspect of the network externalities is economies of scope. An individual (exporter, importer, borrower, lender, or currency trader) is more likely to use a given currency in his or her transactions if everyone else is doing so. If a currency is widely used to invoice trade, it is more likely to be used to invoice financial transactions as well. If it is more widely used in financial transactions, it is more likely to be a vehicle currency in foreign exchange trading. If

\footnotetext{
${ }^{7}$ For example, Tavlas and Ozeki (1992)
} 
it is used as a vehicle currency, it is more likely to be used as a currency to which smaller countries peg. And so forth.

\section{F. The Twentieth Century}

When pondering the prospects for the renminbi to become an international currency, it helps to look to history. The remainder of the paper turns to an examination of historical record-first qualitative and then quantitative.

During the course of the twentieth century, three major national currencies rose to international currency status: the dollar in the first half of the century and the mark and the yen over the two decades following the 1971-73 breakup of the Bretton Woods system. The three cases differ in many respects, including the terms on which the currencies ended the century. But there are some commonalities in the circumstances in which each rose to international currency status, which may hold lessons for the renminbi.

We will consider briefly the internationalizations of the three currencies. One striking conclusion is that in none of the three did nationalist sentiment initially push the international role for the currency. Typically, the public was indifferent, having surprisingly little desire to walk the world stage. Businessmen were often outright opposed, fearing that a surge in demand for the currency would drive up its foreign exchange value and hurt their competitiveness. The interests of the financial sector did little to counterbalance the interests of the manufacturing sector. To be sure, some deliberate policy steps were taken that facilitated internationalization, but they were mostly pursued by a very small elite that did not have widespread support for its actions. Generally, the internationalization occurred as an unplanned side effect of the economic and financial expansion of the country in question.

We will conclude by reporting the conclusions of an econometric analysis of three fundamentals to determine whether a currency is suited for international status. The first is the size of the home economy, as measured by GDP or trade. The second is confidence in the value of the currency, as measured by the long-term trend in its exchange rate, the variability of the exchange rate, the country's long-term inflation rate, and its position as an international net creditor. The third is the development of its financial markets, particularly their depth, liquidity, dependability, and openness.

A fourth question is more controversial: When the fundamental strengths of one currency come to surpass those of others, does the international role of the rising currency evolve quickly (perhaps accelerated by a tipping phenomenon) or only slowly (gradual adjustment due to inertia)? ${ }^{8}$

\footnotetext{
${ }^{8}$ The determinants of international currency status are examined in Frankel (1992); Eichengreen and Frankel (1996); Chinn and Frankel (2007, 2008). Those papers in turn drew on Aliber (1966); Bergsten (1975); Black (1985, 1989); Cohen (1971); Kenen (1983); Swoboda (1969); and other references cited within. For more recent overviews of the subject, see Genberg (2009), Goldberg (2010), and
} 


\section{The Rapid Ascent of the Dollar after 1913}

At the dawn of the twentieth century, Victoria still reigned as Queen and the pound sterling still reigned as supreme currency. Historians estimate that roughly 60 percent of the world's trade was invoiced in sterling in the late nineteenth century. ${ }^{9}$ In 1899 , the share of pounds in known foreign exchange holdings of official institutions was almost two-thirds, more than twice the total of its nearest competitors, the French franc and German mark. ${ }^{10}$ The dollar did not even make the running.

The ranking of the four currencies remained the same in 1913. By 1917, however, the dollar had emerged as a major international currency. Foreign central banks had begun to hold dollar reserves and the currency was increasingly used in trade and finance. Historians debated whether the dollar dethroned the pound soon thereafter in the 1920s or whether it merely joined the list of major international currencies at that point. Either way, the dollar's rise as an international currency after 1913 was rapid. What explains this shift?

Prior to 1913, the dollar's main problem was not size (the first criterion for an international currency) since the U.S. economy had surpassed the UK economy, at least as measured by national output, in $1872{ }^{11}$ Rather, the country lacked financial markets that were deep, liquid, dependable, and open. Indeed, it even lacked a central bank, which was considered a prerequisite for the development of markets in instruments such as bankers' acceptances. Perhaps the dollar also fell short in terms of foreign confidence in its value. For one thing, the United States was still an international debtor. For another, it had a habit of experiencing occasional financial crashes. Indeed the Panic of 1907, which came with a 50 percent fall in the Dow Jones Industrial Average and an 11 percent fall in production, ended only when J. Pierpont Morgan famously locked Wall Street's leaders into his study and refused to release them until they pledged to stand behind its teetering financial institutions. With the lender of last resort function dependent on the actions of a private citizen, international investors had reason to doubt the dollar's future reliability.

Because Morgan would not always be around to play this role, the episode demonstrated the need for a central bank to act as lender of last resort. Senator Nelson Aldrich, having become persuaded of this need, convened a meeting of six "duck hunters" on Jekyll Island in 1910. The meeting was chaired by financier Paul Warburg and attended by a small group of banking executives, including Benjamin Strong (head of Bankers Trust, representing Morgan). ${ }^{12}$ They

\footnotetext{
Kenen (2011).

${ }^{9}$ Broz (1997, 1999); Schenk (2010).

${ }^{10}$ The source, which has been cited by many, is Lindert (1969). In 1899, known pound reserves were 43 percent of total official reserve holdings, francs 11 percent, and marks 10 percent. In 1913 sterling accounted for 38 percent of total holdings, francs and marks 24 percent and 13 percent.

${ }^{11}$ In 1990 International Gheary-Kamis dollars.

${ }^{12}$ Among those who have told this interesting story are Broz (1997, 1999), Eichengreen (2011a), Eichengreen and Flandreau (2010,
} 
produced the Aldrich Plan, which eventually became the law establishing the Federal Reserve.

There is no question that this was a small elite taking steps that did not have broad support. Attempts to found a national bank earlier in American history had foundered on populist suspicion of Eastern banking interests, and this attempt would have met the same fate had the public known the circumstances of its genesis. The six conspirators acted in extreme secrecy during their supposed duck hunting trip on Jekyll Island, and kept the secret for three years. Despite their precautions, and a proposed organizational structure deliberately designed to disperse control beyond an Eastern banking establishment, populist opposition to the foundation of the Federal Reserve was strong. The bill passed only in 1913 when a new president, Woodrow Wilson, decided to take ownership of it.

Once the central bank was established, the United States made rapid progress in terms of the third criterion for an international currency - increasing the depth, liquidity, and openness of U.S. financial markets. Eichengreen (2011a) argued that it was the establishment of a market in dollar-denominated trade acceptances among banks that mattered most. As the financial markets developed, so did the international role of the dollar. The onset of World War I accelerated the transformation: large-scale wartime lending by the United States to Britain and other combatants reversed the nineteenth-century creditor-debtor relationship and positioned the dollar as a strong currency - the second criterion for international status.

All this happened without desire, whether on the part of the public or politicians, for international prestige or power on the world stage. The law creating the Fed squeezed through Congress because of the shock of the financial panic of 1907, not because Congress aspired to boost the dollar's international standing. Indeed, there was plenty of evidence that, even though the world was now ready for a new hegemon and the United States had the heft to play that role, it did not have the awareness, interest, nor skills to do so. The failure of the U.S. Senate to ratify the League of Nations in 1919, the passage of the Smoot-Hawley tariff in 1930, and Roosevelt's torpedoing of the London Economic Conference in 1933 are but three examples of U.S. reticence. According to the hegemonic stability theory of Kindleberger (1973), the resultant lack of global leadership and deficiency in the provision of international "public goods" had dire consequences for all countries. The international monetary system in the interwar period was likened to an orchestra without a conductor.

One would expect that the internationalization of the dollar was in the interest of the business community, or at least the New York financial community. But even here, the majority was not sufficiently interested to lobby for deliberate measures; rather, internationalization of the dollar was an important part of the vision held by the same tiny elite who conspired to establish the Federal Reserve. Broz (1999, p. 31) argues, "Although financial reform was couched in terms of the national interest, Warburg explicitly tied it to improving the international position of the dollar." Karmin (2008, p. 116) concludes, "For the plotters on Jekyll Island, the 
ulterior motive was to profit from the internationalization of the dollar." The outsized influence of the six duck hunters did not end with the establishment of the central bank in 1913. One of them, Benjamin Strong, became the first president of the New York Fed in 1914 and served until his death in 1928. It was he, far more than anyone else, who built up the new institution and nurtured the new international currency in the 1920 s, $^{13}$ for example promoting American lending to Europe. ${ }^{14}$ Another of the six, Frank Vanderlip, president of the bank that was to become Citi, led the way in opening international branches and expanding dollar lending. ${ }^{15}$

Regarding the speed of the dollar's ascent, the traditional view has been that the dollar did not fully supplant the pound until after World War II and that this illustrates the strong inertia in international currency roles and the long lags in responding to changes in the fundamental determinants. Krugman (1984) put the lag at half a century. The inertia is said to result from the network externalities that are intrinsic to the choice of money just as they are in the choice of language. One decides to use the dollar for the same reason that one decides to learn English: everyone else has done it. ${ }^{16}$

The pound made a bit of a comeback in the late 1930s. As late as 1940, the level of foreignowned liquid assets held in sterling was still double those held in dollars. But by 1945, the position of the dollar and pound, as measured by this statistic, had precisely reversed. ${ }^{17}$ The dollar emerged from the war still convertible into gold, but the pound (and other currencies) did not. So the dollar standard became the de facto basis of the Bretton Woods system. Some have placed the date of the pound's dethronement as late as 1954, based on figures of foreign exchange reserve holdings. ${ }^{18}$ That could conceivably imply a lag behind fundamentals as long as eighty years, if one viewed the main determining event as U.S. GNP passing that of the UK in 1872.

A more reasonable view is that the dethronement took place earlier than 1954 and the change in overall fundamentals took place later than 1872, during World War I. This was when the United States attained the other criteria needed for an international currency: a central bank, net creditor status, liquid and open financial markets, and is also when sterling lost its convertibility into gold (the first time) as well as most of its creditor position. ${ }^{19}$ If the fundamentals are

\footnotetext{
13 "It did not bode well that the new 'conductor of the orchestra,' the Federal Reserve, was a deeply divided organization that did not fully realize the role that had been thrust upon it and, but for Strong, would have been in the hands of a motley crew." Ahamed (2009, p. 176).

${ }^{14}$ And in so doing competed with Montagu Norman, head of the Bank of England. Eichengreen (2011, pp. 30-32).

${ }^{15}$ Eichengreen (2011a, pp. 24-27).

${ }^{16}$ Krugman (1984) showed how there can be multiple equilibria in use of an international currency, developing some informal ideas of earlier authors such as Kindleberger (1981), McKinnon (1979), and Swoboda (1969). Matsuyama, Kiyotaki, and Matsui (1993). Rey (2001) also shows the possibility of multiple equilibria in the internationalization of currencies as determined by network externalities and the pattern of international trade.

${ }^{17}$ Aliber (1966, pp. 19-20).

${ }^{18}$ Triffin (1960), Schenk (2010).

${ }^{19}$ In 1915. For example, Nurkse (1944); Bergsten (1975, p. 53); Eichengreen (1992; 2011a, pp. 26-27). Britain famously tried to re-peg to gold in 1925 despite a prescient warning from Keynes. It was forced to give up in 1931, whereupon the dollar share of global reserves reached its interwar peak.
} 
judged to have switched in 1917, and the currency positions to have finally switched in 1945, then the lag was on the order of thirty years.

Others have recently argued that the lag was shorter still. They said that the reserve holding figures were distorted by Britain's insistence that Commonwealth countries be required to hold pounds and be discouraged from spending them on other countries' goods. Eichengreen points to the formation of the sterling bloc in the 1930s and offers the following evidence that the constraint continued to bind after the war. In 1947, when the UK removed restrictions on the use of sterling (as it had agreed to do, under relentless American pressure), Commonwealth countries rushed to sell pounds for dollars, impelling the UK to restore the restrictions. ${ }^{20}$

Eichengreen (2011a); Eichengreen and Flandreau (2008, 2010); Subramanian (2011a, b) argue that the dollar overtook the pound as early as the mid-1920s. The implication was that the lag in this episode was less than ten years. Eichengreen (2011a, p. 32) wrote, "From a standing start in 1914, the dollar had already overtaken sterling by $1925 .,{ }^{21}$

Indeed, if one judges economic size not by GDP but by trade volume (Figure 1), then the implication is that the lag was even shorter. The level of U.S. exports first surpassed UK exports during World War I. The difference was very small throughout the 1920s and 1930s. Not until World War II did U.S. trade pull definitively ahead of UK trade. Either way, the argument was that the transition in currency status was actually rather sudden, and that the dollar could fall from grace just as quickly today. ${ }^{22}$

Figure 1. U.S. and UK Exports, 1900-1957

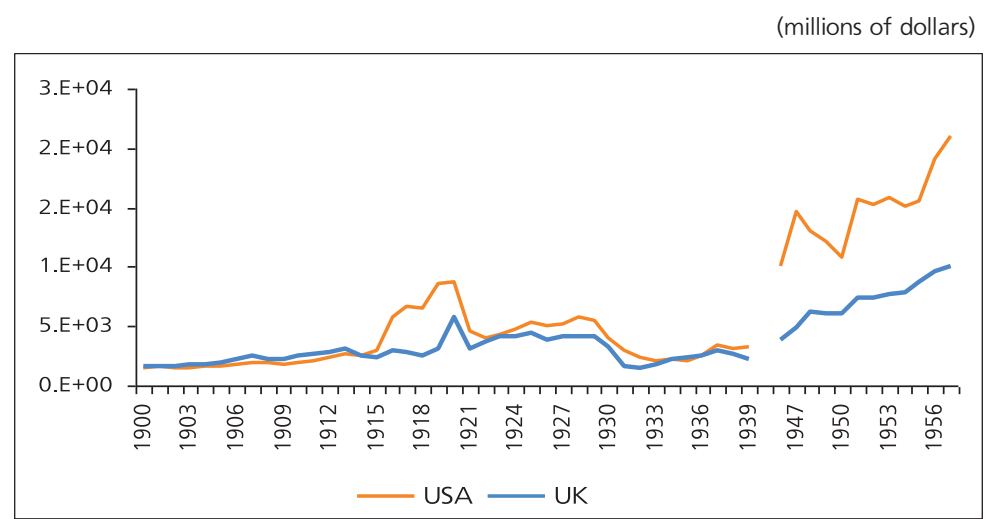

Source: UK Export Data: Department of Trade and Industry, UK; UK exchange rate (1946-1970): Global Financial Data; U.S. Export Data: Historical Statistics of the United States, Colonial Times to 1970, U.S. Census Bureau.

\footnotetext{
${ }^{20}$ Eichengreen (2011a); Eichengreen and Flandreau (2010).

${ }^{21}$ Subramanian (2011a) adopts the argument that the lag was "considerably less than the 60-plus years conventionally believed and closer to 5 or 10 years (from 1919 to the mid-to-late 1920s)."

${ }^{22}$ Eichengreen (2011a, p. 33); Subramanian (2011a, b).
} 


\section{The Brief Ascent of the Deutsche Mark after 1973}

The Deutsche mark attained such a high degree of confidence and prestige in the latter part of the twentieth century that it is easy to forget how short its life was. It was born in Ludwig Erhard's currency reform of 1948, replacing the Reichsmark (which itself had been created in 1924 , in the aftermath of the German hyperinflation of 1921-23). The Bundesbank was not founded until 1957.

By 1958, the period of dollar shortage ${ }^{23}$ had ended and European currencies restored convertibility. ${ }^{24}$ Almost immediately, a rising U.S. balance of payment deficits and declining ratio of U.S. gold reserves to dollar liabilities brought into question the long-term prospects for the dollar. This was the dilemma that Triffin (1960) had predicted. But the trend was greatly accelerated by the U.S. government's Vietnam-era spending, which was not matched by a willingness to raise taxes to pay for it, but rather accompanied by monetary expansion and inflation. The second criterion for the dollar's international status - its long-term credibility as a store of value - was put in doubt.

The American response to this challenge revealed, again, how currency internationalization tends to come fairly low down a country's priority list. U.S. government policy sought to protect the balance of payments, but not the internationalization of the dollar. The Treasury instituted capital controls such as the Interest Equalization Tax. The controls together with financial repression in the banking system (reserve requirements and Regulation Q's ceiling on the interest rate that banks were allowed to pay their depositors) resulted in the relocation of banking business offshore, beginning with the Eurodollar market in London. ${ }^{25}$

President Richard Nixon took the dollar entirely off gold in 1971 and the fixed exchange rate system definitively ended in 1973. U.S. inflation and depreciation further impaired the international attractiveness of the dollar as a store of value. The United States was seen to be neglecting its responsibility to provide the "public good" of a stable anchor for the world monetary system. ${ }^{26}$ The depreciation of the dollar was concentrated particularly in four major episodes, one per decade: 1977-79, 1985-88, 1993-95, and 2002-08. In each episode the dollar exchange rate became an issue of conflict between the United States and its trading partners, Europe in particular. American treasury secretaries were periodically faulted for a policy of benign neglect of the dollar's value. Presumably as a result, the share of dollars in

\footnotetext{
${ }^{23}$ Kindleberger (1950).

${ }^{24}$ McKinnon (1979, p. 5).

${ }^{25}$ McCauley (2011, p. 3): "U.S. policy promoted the dollar offshore market as a side-effect of a misguided defence of the dollar's gold link."

${ }^{26}$ The French had been complaining since the 1960s of the dollar's "exorbitant privilege." Providing an alternative to the dollar was part of the motivation when French president Valerie Giscard d'Estaing and German Chancellor Helmut Schmidt sought European monetary cooperation and in 1979 produced the short-lived ecu.
} 
international reserves began a long-term decline after 1977 (Figure 2).

Figure 2. Share of the Dollar in Foreign Exchange Reserve Holdings, 1965-2010

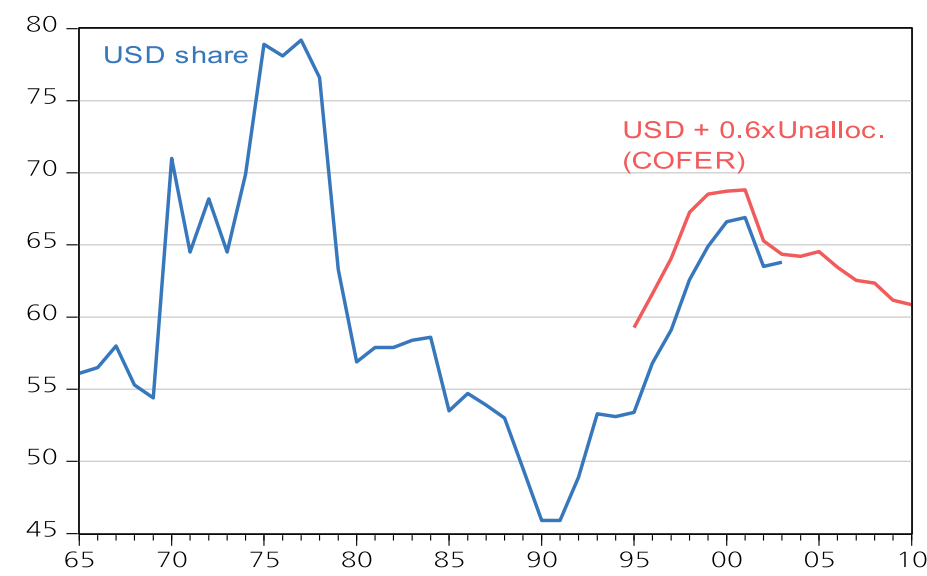

Source: Menzie Chinn (The first series is a spliced version of updated 2003 data obtained July 2004, for 1980 onward, to an unpublished data set for 1965-2001. The later series, data from the IMF's Currency Composition of Official Foreign Exchange Reserves, assigns a share of the unallocated residual to U.S. dollars.)

Two newly international currencies, the mark and the yen, began to gain share at the expense of the newly declining dollar and the still declining pound. (See Figure 3.) Mirroring U.S. attitudes toward the internationalization of the dollar, the German attitude toward the mark involved little eagerness to internationalize it. German policy was in fact opposed to internationalization. ${ }^{27}$ In terms of foreign policy, there was an aversion to the idea of strutting the world stage. Domestically, the economically and politically powerful manufacturing sector feared that internationalization would lead to upsurges in the demand for marks, which would result in either further appreciation, if the currency was allowed to float, or in monetary inflows, if the Bundesbank bought up dollars to resist the change in the exchange rate. In the former case, appreciation would immediately hurt exporters' international competitiveness. In the latter case, the same loss of price competitiveness would eventually come, but via the even-lesswelcome channel of inflation.

Frieden (2000) has drawn a distinction between the financial sector, which supports a strong currency, and the manufacturing sector that does not. In colloquial American terms, it is Wall Street versus Main Street. One can see the banking sector weighing in in countries where it is large and powerful: the United Kingdom and Switzerland. But the financial sector is probably too small, relative to manufacturing, to carry much weight in Germany (or, for that matter, in France or Japan).

\footnotetext{
${ }^{27}$ Eichengreen (2011a, p. 67) uses an episode from 1979 to illustrate the Germans' active discouragement of international use of the DM: Iran was considering converting its dollar reserves into deutschmarks, but the Bundesbank warned Tehran to desist.
} 
Nevertheless, the mark continued to gain status throughout the 1980s. The trend took place not because of policy, but in spite of it. It was a side effect of the growing size of the German economy (especially trade) and the impeccable reputation that the Bundesbank had established for keeping the mark strong in value, whether measured by inflation or the exchange rate. By the foreign exchange reserve measure, the currency share reached almost 20 percent in $1989 .{ }^{28}$

That year turns out to have been the peak in the mark's share. Slow economic growth may have been a contributing reason why the mark's share of international reserves stopped rising in the 1990s. Another is that the United States won the Cold War in 1989-91 and began seriously to put its house in order in the mid-1990s, as reflected in the length and strength of that decade's noninflationary economic expansion, the steady elimination of troublesome budget deficits, and the appreciation of the dollar in the second half of the decade.

More importantly, Germany spent the decade preparing euthanasia for its beloved currency. The Maastricht Treaty of 1991 came to fruition in January 1999 when the mark, together with the French franc and nine other continental currencies, went out of existence in the historic creation of the euro. German acquiescence was the ultimate expression of the absence of craving for the political prestige or economic power that an international currency might bring. The motives on Germany's part included a desire to assure its neighbors that they had nothing to fear from the even larger country that had been created by German reunification in 1991. But this is just another illustration of the weakness of nationalistic forces.

As a footnote, the euro is a partial exception to the general phenomenon described in this paper. The motives for its creation were thoroughly political, the ambition to acquire international status baked into it from the beginning. ${ }^{29}$ In realizing this ambition, the euro started with two advantages - that it was the home currency for a bloc that resembled the United States in terms of economic weight, and that it seemed likely to inherit the credibility of the mark. As a result, the euro in its first decade advanced quickly into the ranks of the top reserve currencies. Since 2010, sovereign debt worries have severely dented reasonable expectations of the euro's future. But if the authorities were to respond to the crisis by creating a Eurobond, that wouldonce again as a side effect — give a big new boost to the fundamentals underpinning its role as an international reserve currency.

\section{The Brief Ascent of the Yen after 1984}

The period of internationalization of the yen can be divided into halves. The first period was the 1980s, when international use of the yen trended upward even though domestic politics was

\footnotetext{
${ }^{28}$ Tavlas (1993, pp. 566-79).

${ }^{29}$ For example, the decision to create 500-euro notes was a rare instance of a currency's guardians deliberately seeking international seignorage, at the expense of others and even at the expense of law enforcement. Rogoff (1998).
} 
opposed to internationalization and government policy was at best neutral toward it. The Japanese feared that increased demand for their money would hurt export competitiveness, just as the Germans did. In the subsequent period, policy sought actively to promote internationalization but it was too late as economic fundamentals had already turned around, dominated by the shrinking economy.

After World War II, Japan's export-driven economic miracle allowed its currency to meet the first criterion for internationalization. The country's weight grew rapidly, both in terms of its share of global GDP and in terms of share of global trade. But it was slower to meet the other criteria. Only during the period 1960 - 73 did the government begin to allow foreigners to acquire some types of assets in Japan. Only in 1964 was full current account convertibility under the IMF Articles of Agreement restored. ${ }^{30}$

After the breakup of the Bretton Woods system (1971-73), central banks around the world began gradually to hold some yen as foreign exchange reserve, especially as the Bank of Japan began to establish a reputation for a currency that strengthened in value. But other measures of internationalization, such as use of the currency in invoicing trade or denominating debt, continued to show a very low share for the yen. (In 1979, only 25 percent of Japanese exports and 2 percent of imports were denominated in yen.) This is not surprising since Japanese financial markets remained uncompetitive, highly regulated, and mostly closed to foreigners. The monetary authorities intervened to prevent the yen from appreciating in 1976 and 1977, another sign that the internationalization of the yen mattered less than the interests of Japan's exporters. ${ }^{31}$

In 1979 - 80, the government began to allow foreign residents to hold a fuller range of domestic assets). But politics and policy continued to oppose internationalization. The Foreign Exchange Law of 1980 still allowed "minimum necessary controls" on capital flows to manage the exchange rate or balance of payments. When further liberalization came, gaiatsu - foreign pressure from the United States - was the main driving force. Six months of negotiations between the two countries produced the Yen/Dollar Agreement in 1984. The main political motive, which had become strong enough to counterbalance the fears of domestic manufacturers that they might lose competitiveness, was to satisfy U.S. demands, in fear that the alternative of allowing protectionist sentiment to grow in the U.S. Congress would be worse. Support for internationalization from the Japanese financial sector was negligible. This balance of political forces is illustrated by the content of the Yen/Dollar Agreement. In addition to agreeing to the demands to further lift capital controls and to internationalize the yen, the government also agreed to give more favorable treatment to U.S. banks and financial institutions wishing to do business in Japan. It did not agree to immediate and complete deregulation of domestic financial markets, however.

\footnotetext{
${ }^{30}$ Takagi (2011).

${ }^{31}$ Frankel (1984); Takagi (2011) and other references cited therein.

${ }^{32}$ Frankel (1984); Takagi (2011, pp. 1, 3-4). The yen's share in central banks' foreign exchange reserve holdings did rise after 1984 , as the graph shows.
} 
The U.S. motive in pushing for internationalization of the yen was a theory that it would lead to appreciation and help U.S. exporters. This did not happen at first: U.S. interest rates in 1984 were well above those in Japan, so that the removal of remaining capital controls allowed an acceleration in the net outflow of capital from Japan rather than the reverse. The sharpest appreciation of the yen came instead between 1985 and 1987, and was usually associated with the Plaza Accord, in which Japan agreed with the United States and Europeans to intervene in foreign exchange markets to push the dollar down. ${ }^{33}$ By this time, Japan's position in international trade was so strong that the insecurity shown by the postwar slogan "export or die" had begun to ease.

Some in Asia today believe that these American efforts to appreciate the yen - the Yen/ Dollar Agreement and the Plaza Accord - were deliberate attempts to sabotage the Japanese economy and that they were ultimately successful in that aim in the 1990s. This conspiracy theory goes one step too far. It is important to recall the three-year episode that led to the Japanese crash of the 1990s: the 1987-89 bubbles in Japan's stock market and real estate market. During the bubble period, the Japanese authorities no longer intervened in favor of a strong yen, but if anything sought to prevent the dollar from depreciating further. ${ }^{34}$ In retrospect, the Bank of Japan's monetary policy was too easy during this period (the same mistake the Fed made in 2005-2006). . $^{35}$

International use of the yen continued gradually to rise in the $1980 \mathrm{~s} .{ }^{36}$ Its share of foreign exchange reserves reached almost 9 percent in 1991 (Figure 2). That turned out to be the peak. Most commentators, however, distracted by the continued dizzying appreciation of the yen against the dollar from 1990 to 1995 , failed to notice that the trend in the 1990s had shifted back toward the rising international use of the dollar. ${ }^{37}$ Indeed, it was fashionable to pronounce that the United States was in decline as a world power, especially relative to Japan, ${ }^{38}$ and that the dollar was in decline as an international currency, especially relative to the yen.

\footnotetext{
${ }^{33}$ Funabashi (1988); Dominguez and Frankel (1993).

${ }^{34}$ In 1987 and 1988, the Ministry of Finance used administrative guidance to encourage Japan's institutional investors to hold more dollars than they would have freely chosen to do (Dominguez and Frankel, 1993, p. 19).

${ }^{35}$ Ironically, the Japanese conspiracy theory around the time of the crash was that the United States had been to blame for the easy monetary policy of 1987-89 by persuading the Japanese authorities to buy up large quantities of dollars. It seems unlikely that Japan's crash in the 1990s was attributable both to U.S. pressure on Japan to push the dollar down in 1984-86 and U.S. pressure on Japan to keep the dollar up in 1987-89.

${ }^{36}$ Tavlas and Ozeki (1992).

${ }^{37}$ Frankel (1995, pp. 9-16).

${ }^{38}$ Kennedy (1989), Fingleton (1995).

${ }^{39}$ Hale (1995); Kindleberger (1995).
} 
Figure 3. Reserves Held by Central Banks as Shares of Total — Major Currencies, 1973-2010

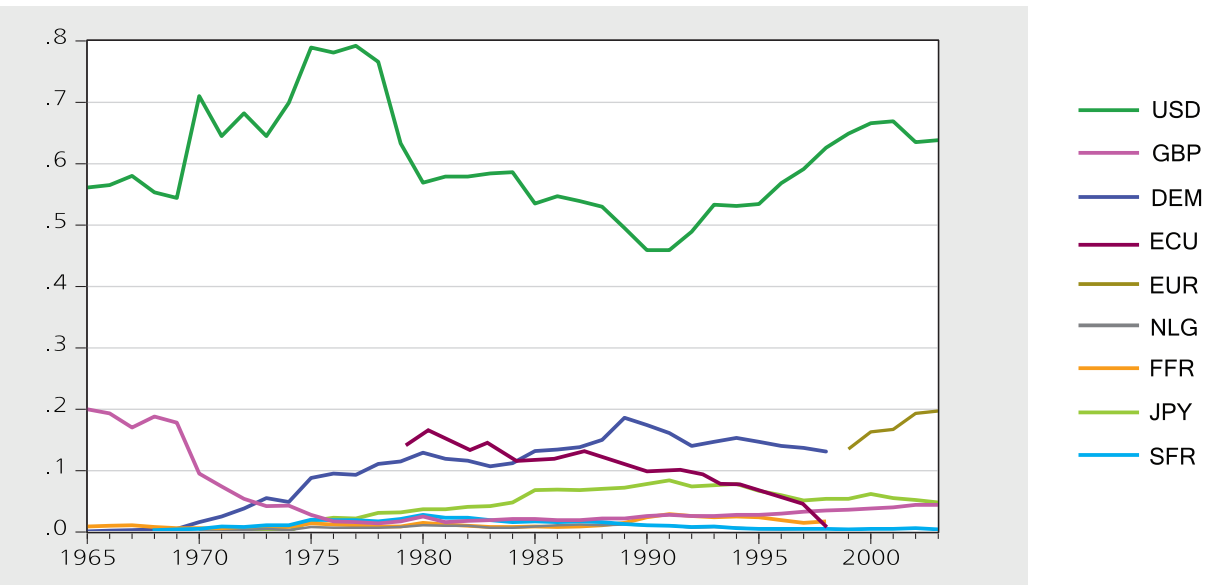

Note: Estimated currency shares of reserves of all central banks, year end, 1965-2003. "Other currencies" omitted. Source: IMF, Annual Reports, Chinn and Frankel (2008), Chinn (2012).

In the 1990s, official policy at last shifted firmly in favor of internationalization, with the aims of reducing exchange rate risk for domestic firms, facilitating business for Japanese banks and other financial institutions, and promoting Japan as a financial center. ${ }^{40}$ The prime minister in 1996 announced a comprehensive package of financial liberalization. The resulting "big bang" of 1998 did not live up to its advance billing, however. Further attempts were made to reverse what by now was the decline in the status of Tokyo as one of the world's top financial centers. ${ }^{41}$ This work continued, indeed intensified, into the next decade. But it became progressively more evident that the effort had failed. Indicators showed the yen's international use was shrinking. The decline was an effect of the ills afflicting Japan's real economy, which had shown hardly any growth since the bursting of the land and equity bubbles at the start of the 1990s. "By the end of 2003, it was clear that any further attempt to internationalise the yen would be futile without a fundamental change in the economic might of Japan." yen received safe haven capital inflows after the global financial crisis of 2008, attained a high in the nominal exchange rate in 2011, and remains an international currency that ranks above the Swiss franc and roughly as high as pound sterling, ${ }^{43}$ its rise as an international currency peaked twenty years ago.

\footnotetext{
${ }^{40}$ Takagi (2011, p. 1); MoF (1999).

${ }^{41}$ Ministry of Finance (1999), Takagi (2011, pp. 5-6).

${ }^{42}$ Takagi (2011, p. 9).

${ }^{43}$ The yen still beats out the pound for the number three position in foreign exchange turnover and derivative turnover. (See Tables A2, A3, and A6 in the Appendix.) However, the pound now once again dominates the yen in currency composition of international debt, foreign exchange reserve holdings and denomination of bank liabilities. (See Tables A1 and A4, Figures A1 and A2.)
} 


\section{Statistical Estimation of Adjustment of Reserve Currency Shares to Fundamental Determinants}

The period during which the mark and the yen rose to true international currency status (1975-90), surpassing the pound and Swiss franc for the number 2 and number 3 slots, offers the opportunity to ascertain empirically how quickly foreign exchange reserve holdings adjust to economic fundamentals. Shares in central banks' foreign exchange reserve holdings are the most important measure of international currency status as well as the most easily measured.

A number of attempts have been made to estimate statistically the determinants of reserve shares. $^{44}$ The period $1973-98$ is just barely long enough to get useful econometric estimates regarding the influence of the major determinants of the shares of five international currencies (dollar, mark, yen, pound, Swiss franc). It does not include the once-in-a-century phenomenon of one currency overthrowing another in the number one slot. But it is possible to put together a decent set of consistent data over this period, and the twenty-five-year period does neatly include the rise of the mark and yen.

Estimates reported here use IMF annual data on aggregate central bank holdings of the relevant major currencies. The data set ended in 1999, because that was when the mark and franc went out of existence. ${ }^{45}$ It did not extend further back than 1973 because we need data on all three fundamental determinants, not just on country size and confidence, but also on the depth of the countries' financial markets. We use the volume of turnover in the foreign exchange market as a measure of depth of the countries' financial markets, and measure confidence in the currency's value using trend inflation, trend depreciation, exchange rate volatility, and international asset position. ${ }^{46}$

Figure 4 shows foreign exchange turnover (as a share of total) in the countries corresponding to the key reserve currencies. The size of the London market is impressively large, and rising, in contrast to the shares of Frankfurt and Tokyo, which are smaller and declining.

\footnotetext{
${ }^{44}$ A number of scholars were able, for this purpose, to gain access to country-by-country data on reserve holdings, which are otherwise extremely confidential. See Dooley, Lizondo, and Mathieson (1989); Eichengreen and Mathieson (2000).

${ }^{45}$ Chan, Peng and Shu (2011, p. 135) apply a very similar approach to a post-euro data set (1999-2006), but their measures of the currencies' ability to keep their value (inflation and exchange rate volatility) are not statistically significant, which they interpret as "probably reflecting the short sample period." Leaving this factor aside, and assuming hypothetically that China achieved full financial market development, they inferred from the estimates that the yuan could quickly attain the same international currency status as the yen and pound today.

${ }^{46}$ Chinn and Frankel (2007; 2008, pp. 49-73).
} 
Figure 4. Foreign Exchange Turnover in Financial Center as a Share of Total Turnover

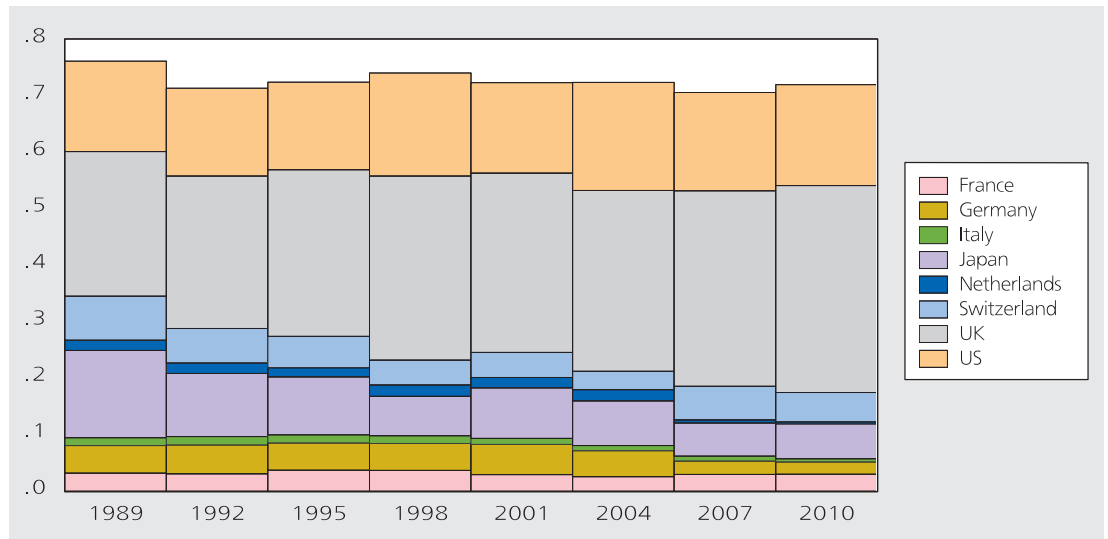

Source: BIS, Triennial Central Bank Survey, various issues; Chinn (2012).

A preliminary examination of the relationship between the currency shares and GDP at market rates, or GDP in PPP terms, suggests two propositions. First, it does not seem that the difference between GDP measured at market rates or in PPP terms is essential for our purposes. Second, it is apparent that the relationship between currency shares and GDP shares is nonlinear. The curve must turn sharply upward somewhere in the middle. (See Figure 5.) This consideration, and the realization that no currency share can fall below zero or rise above 100 percent, leads us to the logistic as the functional form. The standard logistic transformation is symmetric, and has a maximal slope at share $=0.50$. When we plot the logistic of the currency share against the size variables, a straight line fits the data much more comfortably, indicating that the logistic may be a good guess.

Figure 5. Currency Share versus GDP Share

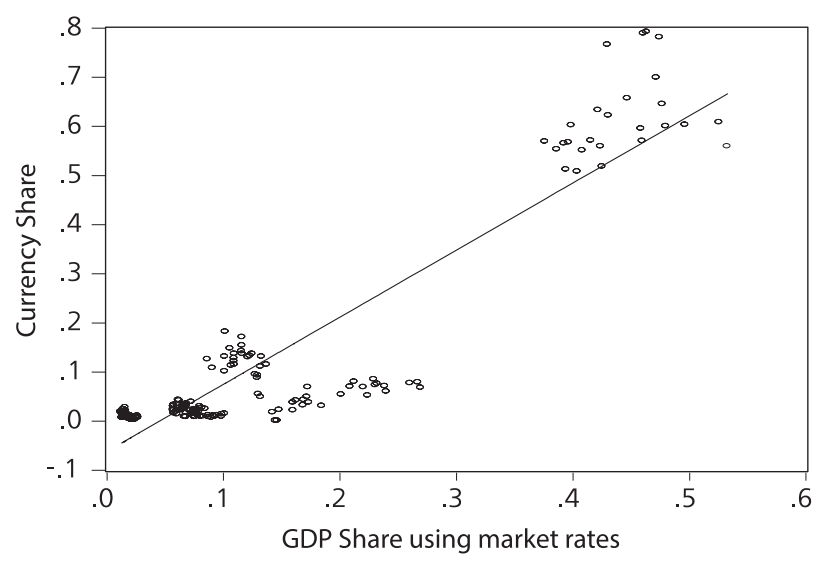

Source: Chinn and Frankel (2007) 
Table 2. Panel Regression for Determination of Currency Shares

\begin{tabular}{|c|c|c|}
\hline \multicolumn{2}{|c|}{ Dependent variable: Logit of currency shares in reserve holdings } \\
$\log ($ share/[1-share] $)$
\end{tabular}

Note: GDP at market rates, Significance level $*(10 \%)$, Estimated using OLS.

The functional form that seems to fit the data well is called a logit. It allows a change in fundamentals from 50 percent to 51 percent to have a far bigger effect on currency shares than a change from 0 to 1 percent. This tipping phenomenon is one manifestation of network externalities in the choice of an international currency. Table 2 reports the results of one equation. The fundamental factors of GDP, the inflation differential, and exchange rate variability all appear statistically significant. Foreign exchange turnover is also of the hypothesized sign, but is not significant in this particular regression. ${ }^{47}$

The effect of the lagged reserves variable is of great interest. In this equation, its coefficient is estimated at 0.85 . That means that, each year, the currency shares move 15 percent of the way toward their long-run equilibrium. The half-life of the adjustment process is four years ( 0.85 to the fifth power is 0.5 ). For concreteness, if one country's fundamentals, such as size, register a sudden leap from 70 percent of a rival's level to 110 percent, the prediction is that its reserve currency share will reach 90 percent of its rival's after four years and 100 percent after eight years. (Some other versions of the equation give substantially slower speeds of adjustment.)

Table 3 reports further variations of the regression equations reported in Table 2. The estimated effects of size, the inflation differential, and the lagged endogenous variable are robust. The statistical significance of the other measures of rate of return (depreciation and exchange rate variability) and of foreign exchange market turnover depends on the precise specification.

\footnotetext{
${ }^{47}$ Turnover becomes statistically significant if we also include a dummy variable for the leader, that is, for U.S. holdings, or if the yen is excluded from the sample. Surprisingly, we did not find a significant role for net international asset position.
} 
Table 3. Determinants of Reserve Currency Shares: during the Rise of the DM and Yen Panel Regression (1973 1998)

Dependent variable: logit of share of major currencies in central banks' holdings of foreign exchange reserves $\log (\operatorname{sh} /[1-s h])$

\begin{tabular}{|c|c|c|c|c|c|c|c|}
\hline & [1] & {$[2]$} & [3] & {$[4]$} & {$[5]$} & {$[6]$} & [7] \\
\hline \multirow{2}{*}{ Constant } & $-0.506^{*}$ & $-0.648^{*}$ & $-0.497 *$ & $-0.674 *$ & $-0.488 *$ & $-0.487^{*}$ & $-0.117^{*}$ \\
\hline & $(0.123)$ & $(0.154)$ & 0.124 & $(0.154)$ & $(0.138)$ & (0.138) & $(0.061)$ \\
\hline \multirow[t]{2}{*}{ GDP ratio } & $2.285^{*}$ & $2.768^{*}$ & $2.735^{*}$ & $3.690 *$ & $2.215^{*}$ & $2.775^{*}$ & $1.040^{*}$ \\
\hline & $(0.564)$ & $(0.643)$ & $(0.781)$ & $(0.923)$ & $(0.616)$ & $(0.854)$ & $(0.288)$ \\
\hline \multirow[t]{2}{*}{ Inflation differential } & $-1.565^{*}$ & $-2.639 *$ & $-1.512 *$ & $-2.860 *$ & & & \\
\hline & $(0.927)$ & (1.156) & $(0.930)$ & (1.164) & & & \\
\hline \multirow[t]{2}{*}{ Depreciation } & & & & & -1.079 & -0.920 & $-1.095^{*}$ \\
\hline & & & & & $(1.294)$ & $(1.306)$ & $(0.594)$ \\
\hline \multirow{2}{*}{$\begin{array}{c}\text { Exchange rate } \\
\text { variance }\end{array}$} & -0.445 & -0.981 & -0.594 & $-1.395^{*}$ & -0.583 & -0.798 & $-1.251^{*}$ \\
\hline & $(0.457)$ & $(0.573)$ & $(0.491)$ & $(0.644)$ & $(0.581)$ & $(0.624)$ & $(0.341)$ \\
\hline \multirow[t]{2}{*}{ Forex turnover ratio } & & 0.446 & & $0.576^{*}$ & 0.208 & 0.252 & 0.427 \\
\hline & & $(0.289)$ & & $(0.303)$ & $(0.302)$ & $(0.305)$ & $(0.145)$ \\
\hline \multirow[t]{2}{*}{ GDP leader } & & & -0.125 & -0.217 & & -0.150 & \\
\hline & & & $(0.150)$ & $(0.156)$ & & 0.159 & \\
\hline \multirow[t]{2}{*}{$\operatorname{Lag} \log \left(s h_{t-1} / 1-s h_{t-1}\right)$} & $0.879^{*}$ & $0.851^{*}$ & $0.882 *$ & $0.846^{*}$ & $0.881^{*}$ & $0.882^{*}$ & $0.957^{*}$ \\
\hline & $(0.025)$ & $(0.031)$ & $(0.025)$ & $(.031)$ & $(.029)$ & $(.029)$ & $(.014)$ \\
\hline Number of observations & 182 & 182 & 182 & 182 & 182 & 182 & 156 \\
\hline Sample period & $1973 \sim 98$ & $1973 \sim 98$ & $1973 \sim 98$ & $1973 \sim 98$ & $1973 \sim 98$ & 1973 98 & $1973 \sim 98$ \\
\hline Adjusted $\mathrm{R}^{2}$ & 0.97 & 0.97 & 0.97 & 0.97 & 0.97 & 0.97 & 0.99 \\
\hline
\end{tabular}

Note: GDP at market terms, Estimated using OLS. Significance level *(10\%), Column [7] omits Japanese yen and estimates using cross-section weighted standard errors.

Subramanian (2011a, b) pursues a similar econometric approach but extends the reserve data back to 1900, with a gap between 1929 and 1958. The advantage is that the sample spans the period when the dollar overtook the pound. The disadvantage is that he has to omit any measure of the depth of financial markets or of the rate of return. He finds that size (which in his case is trade) is a very powerful predictor, and he also finds a role for countries' net creditor status (significant at the 10 percent level).

What are the prospects for China's yuan and the currencies of the other "BRIC" emerging market economies, Brazil, Russia, and India? ${ }^{48}$ Figure 6 shows the IMF's forecasted 2017 GDP

\footnotetext{
${ }^{48}$ Other candidate reserve currencies include the Australian and Canadian dollars. Both countries are relatively small in terms of GDP, though by some metrics their currencies are closer to meeting the requirements. $4 \%$ of foreign exchange trading takes place in Australia, while turnover in the Australian dollar exceeds that of the Swiss franc ( $7.6 \%$ vs. $6.4 \%$, out of $200 \%)$. The Singapore dollar and Swedish and Norwegian currencies are also currently well-represented in central bank reserve holdings, under the category of "other currencies" (Eva Szalay, "Survey: Central Banks Shun Euro, Eye Non-Traditional Reserves," WSJ.com, April 17, 2012.) As of December 2011, "other currencies" represented 5\% of allocated reserves, and $2.8 \%$ of total reserves (IMF, 2012).
} 
levels for the four emerging market economies, along with the United States and the UK.

Figure 6. GDP for US, UK, Brazil, Russia, India, and China: evaluated at market exchange rates.

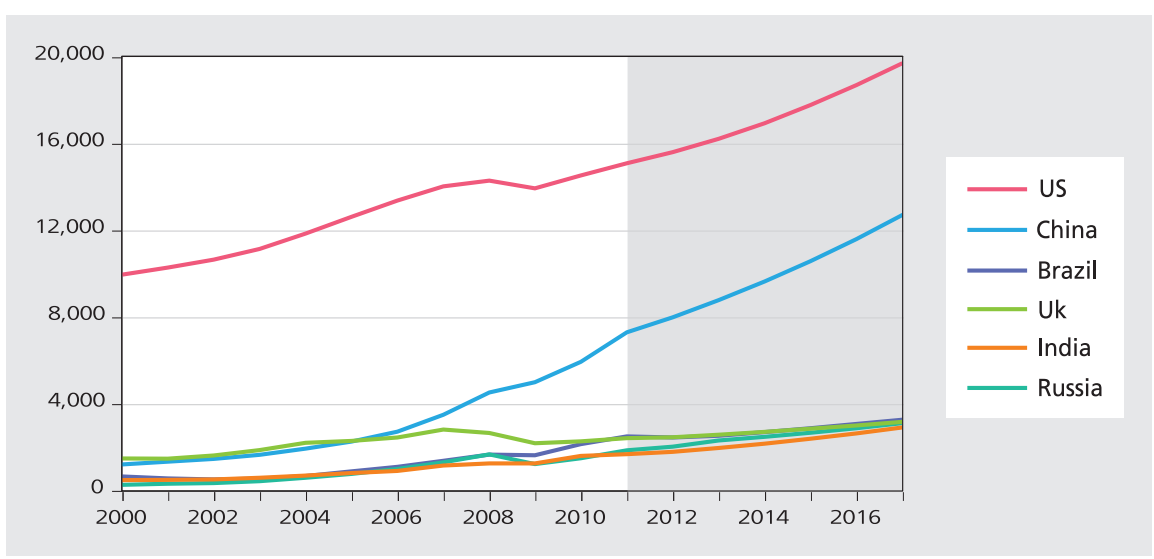

Note: Forecast data 2011 onward (except US and UK: 2012 onward), US Dollar billion Source: Chinn (2012) and World Economic Outlook (April 2012) database.

All four emerging market economies will not exceed US GDP (at market exchange rates) in the next five years, but China's GDP surpassed UK GDP in 2005 and Japan's GDP in 2009. Brazilian GDP is currently approximately on par with that of the UK. By 2017, Russia and India are projected to have matched the UK as well.

Figure 7. De jure Financial Openness Index.

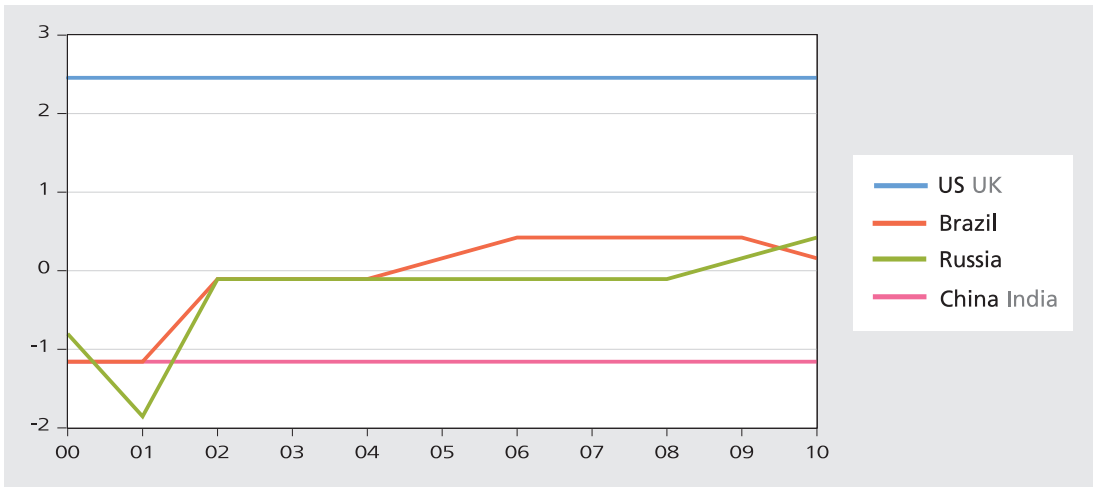

Note: Higher values denote higher financial openness, Chinn-Ito financial openness indicators, KAOPEN Source: Chinn (2012).

Figure 7 plots the Chinn-Ito (2008) financial openness indicators, KAOPEN. This index is the first principal component of binary measures pertaining to restrictions on current account 
and capital account transactions, as well as the requirement for surrender of export proceeds and the existence of dual exchange rates. ${ }^{49}$ The figure highlights the fact that, according to the rules and regulations reported to the IMF, China and India lag far behind Russia and Brazil in terms of financial openness, which in turn lag far behind the US and UK, as one would expect.

\section{Conclusion}

What lessons can we draw from the experience of the past century? What lessons, in particular, can be drawn for the international currency prospects of the latest contender, the renminbi? ${ }^{50}$

Could China's currency now be in the same position as the U.S. dollar at the time of World War I, poised to make a rapid ascent and even rival the position of the historical leader? This is what Subramanian (2011a, b) concludes, enthusing that the renminbi might overtake the dollar around 2022. Such analysis is based on the calculation that at current rates of growth, the Chinese economy may overtake the U.S. economy within a decade, even by the GDP criterion for size, let alone by trade criterion. ${ }^{51}$ Another determinant consistent with this conclusion is the prospective rate of return; everyone expects the RMB to appreciate against the dollar in the long run. ${ }^{52}$ China is a creditor and is still running large surpluses while the U.S. is a debtor and is still running large deficits.

But the third criterion for international currency status is conspicuously missing: deep, liquid, open capital markets.

On the one hand, the last few years have seen a number of substantive steps toward the liberalization of China's currency:

- Chinese firms have begun over the last two years to use the RMB in international trade.

- Foreign central banks have been able to hold RMB since August 2010. (Malaysia's went first, buying RMB bonds for its FX reserves, in September 2010.)

- A "dim sum" market has been now developing in Hong Kong. Between 2007 and 2010, 62 billion RMB bonds (27 batches) were issued offshore including by McDonald's. The Bank of China in Hong Kong launched an RMB bond index on December 31, 2010.

- In November 2010, RMB deposits in Hong Kong reached 280 billion RMB.

\footnotetext{
${ }^{49}$ See Chinn and Ito (2008) for details. Data are available at: http://web.pdx.edu/ ito/Chinn-Ito_website.htm

${ }^{50}$ The literature is exploding as rapidly as the use of the RMB. It includes Chen, Wang, and Yang (2000); Li and Liu (2007); Dobson and Masson (2009); Ito (2010); Park and Song (2010); Lee (2010); Wu, Pan, and Wang (2010); Ranjan and Prakash (2010); Eichengreen (2011b); Fratzscher and Mehl (2011); Kawai and Takagi (2011); McCauley (2011); Chen, Peng, and Shu (2011); Gao and $\mathrm{Yu}$ (2011); and Chen and Cheung (2011).

${ }^{51}$ China's economy passed Japan's in 2010 to attain the world's number 2 ranking.

${ }^{52}$ Indeed expectations of appreciation are the reason for the strong portfolio capital inflows since 2004. Prasad and Wei (2007).
} 
- In June 2012 the authorities revealed that Chinese firms in Shenzhen would be allowed to borrow RMB from Hong Kong banks (echoing Shenzhen's designation 32 years ago as the first special economic zone for international trade and investment). ${ }^{53}$

On the other hand, however:

- China's financial markets are still not very open, as Figure 7 illustrates.

- Cross-border capital flows remain subject to heavy controls. Foreign companies still cannot borrow in mainland China.

- RMB bonds and deposits in Hong Kong are only small as a fraction of total RMB bonds and deposits (and of course Hong Kong is in any case part of China).

- Development of China's domestic financial market has just begun.

- It is still very highly regulated; the domestic system is "financially repressed."

In short, by the criteria of liquidity, breadth, and openness, Chinese financial markets still have a long way to go before they catch up with those of other major currencies. For this reason, the renminbi in 2010-2011 has only just begun to act as an international currency. For example, by 2011, China's currency had climbed in the rankings only to number 21 when measured by the currency composition of international debt (behind the South African rand, (up from 15, behind the Russian rouble, in 2001-05; Appendix 3). It had climbed to number 17 in foreign exchange market turnover (behind the Russian rouble). And so on.

The government in Beijing since 2010 has deliberately pursued offshore international use of the currency. In principle, it could accelerate the financial market development necessary to realize this goal. But if it were to do that, it would be acting contrary to the three precedents examined here, the dollar, mark, and yen. Moreover, it would be doing so despite the tremendous importance of its manufacturing sector relative to its financial sector, which would make one expect a reluctance to internationalize the currency, for the same competitiveness reasons as in the earlier cases. As Subramanian admits, "For China, therefore, there is a tension between the export-led growth strategy, which requires denying foreigners the ability to buy Chinese assets, and promoting reserve currency status, which requires unrestricted access to foreigners to buy Chinese assets."

Not only does China's announced policy defy the logic of political economy. The country's sequencing of its reforms also appears unorthodox. China is encouraging the use of the RMB outside its borders, not having yet begun to remove its controls on capital inflows or outflows and barely having begun to liberalize domestic financial markets. This is not the usual pattern. McCauley notes, "One cannot find any precedent for the effort of the Chinese authorities to develop an offshore market while keeping in place extensive controls on the cross-border flows

\footnotetext{
${ }^{53}$ China to Create Special Test Zone for Currency," Financial Times, June 29, 2012.

${ }^{54}$ Subramanian (2011b, p. 5).
} 
of capital. No other country has set out to develop an offshore market."

What is China up to? One can only speculate. But several hypotheses are possible. The first is that the country seeks the advantages of international currency status-Seigniorage, convenience for its firms, and international prestige (often seen to be among the trappings appropriate for a newly arrived economic powerhouse) — and that it puts even higher priority on these goals than on continuing the export-led development strategy that it has been following up to now. The second hypothesis is that it does not fully realize the tension between the goal of internationalization and the goal of keeping the currency competitively valued, and that the offshore strategy is evidence that it thinks it can pursue both simultaneously. A third hypothesis is that the internationalization strategy is the work of an elite few-the Chinese counterparts to the duck hunters of Jekyll Island. This elite might be motivated by the worry that the export led strategy has finally run into limits, especially inflation and a housing bubble. It might recognize the importance of shifting the economy from exports to the domestic sector, and might see financial opening, the easing of financial repression, and RMB appreciation, as contributing to that strategy. ${ }^{56}$ It might feel politically constrained to try out internationalization in limited geographical areas, beginning with Hong Kong, followed by Shenzhen, and so on, much as the Special Economic Zones 30 years ago demonstrated the success of trade opening before liberalization was extended more widely.

These three hypotheses are not necessarily mutually exclusive: the elite few could be appealing to the advantages of international currency status as a way of overcoming the competitiveness fears of others. Hong Kong is an eager participant. But if China is not yet ready to liberalize its domestic financial markets, to legalize capital inflows, or to let the currency appreciate, then full internationalization is probably a long way off.

Received 05 July 2012, Accepted 2 August 2012

\section{References}

Ahamed, Liaquat, 2009, Lords of Finance: The Bankers Who Broke the World (New York: Penguin Press).

Aliber, Robert, 1966, The Future of the Dollar as an International Currency (Frederick Praeger, Publishers, New York).

Alogoskoufis, George, and Richard Portes, 1992, "European Monetary Union and International Currencies in a Tripolar World," in Matthew Canzoneri, Vittorio Grilli and Paul Masson, eds., Establishing a Central Bank: Issues in Europe and Lessons from the U.S. (Cambridge: Cambridge University Press), pp. 273-302.

Bergsten, C. Fred, 1975, The Dilemmas of the Dollar (New York Univ. Press, New York).

\footnotetext{
${ }^{55}$ McCauley (2011, p. 1). Also Prasad and Ye (2012).

${ }^{56}$ The question whether China should allow the renminbi to appreciate is of course highly controversial. See Frankel (2010)
} 
Bergsten, C. Fred, 1997, “The Dollar and the Euro," Foreign Affairs, July/August, 83-95.

Black, Stanley, 1985, "International Money and International Monetary Arrangements," Chapter 22 in Handbook of International Economics, edited by Ron Jones and Peter Kenen (Elsevier Science Publishers).

Black, Stanley, 1989, "Transactions Costs and Vehicle Currencies," Journal of International Money and Finance 10 (4), December: 512-526.

Boughton, James, 2001, "Northwest of Suez: The 1956 Crisis and the IMF," IMF Staff Papers 48, no. 3, 425.

Broz, Lawrence, 1997, The International Origins of the Federal Reserve System (Ithaca, NY: Cornell University Press).

Broz, Lawrence, 1999, "Origins of the Federal Reserve System," International Organization, vol. 53, no. 1, Winter.

Chen, Hong Yi, Wenshen Peng and Chang Shu. 2011. "The Potential of Renminbi as an International Currency," in Currency Internationalisation: Lessons from the Global Financial Crisis and Prospects for the Future in Asia and the Pacific, proceedings of Bank of Korea/BIS seminar on Currency Internationalisation, Seoul, March 19-20, 2009, BIS Papers No. 61 (Bank for International Settlements), December, pp. 125-148.

Chen, Xiaoli, and Yin-Wong Cheung. 2011. "Renminbi Going Global,” HKIMR Working Paper No. 08/2011 (Hong Kong: Hong Kong Institute for Monetary Research, March).

Chen, Yulu, Fang Wang, and Ming Yang, 2000, "Currency Internationalization as a National Competitive Strategy: U.S. Dollar's Empirical Evidence-And a Study on the Issue of Renminbi," Economic Research Journal, vol. 40, no. 2.

Cheung, Wong, Guonan Ma, and Robert McCauley, 2010, "Renminbising China’s Foreign Assets," Working Paper No. 16 (Hong Kong Institute for Monetary Research, June).

Chinn, Menzie, 2012, “A Note on Reserve Currencies with Special Reference to the G-20 Countries," written for the International Growth Centre (IGC), India Central Programme, May 13, 2012.

Chinn, Menzie, and Jeffrey Frankel. 2007. "Will the Euro Eventually Surpass the Dollar as Leading International Reserve Currency?” In R. Clarida (ed.), G7 Current Account Imbalances: Sustainability and Adjustment (Chicago: U. Chicago Press), pp. 285-322. http://www.ssc.wisc.edu/ mchinn/chinn_frankel_euro.pdf .

Chinn, Menzie, and Jeffrey Frankel. 2008. "Why the Dollar Will Rival the Euro." International Finance 11(1): 49-73. http://www.ssc.wisc.edu/ mohinn/Chinn_Frankel_IntFin2008.pdf

Chinn, Menzie, and Hiro Ito. 2008. "A New Measure of Financial Openness.” Journal of Comparative Policy Analysis 10 (3): 309-322. Data on Chinn-Ito index: http://web.pdx.edu/ ito/Chinn-Ito_website.htm

Cline, William, 2005, The United States as a Debtor Nation (Washington, DC: Peterson Institute for International Economics).

Cohen, Benjamin J., 1971 The Future of Sterling as an International Currency (London: Macmillan).

Dobson, Wendy, and Paul Masson, 2009, "Will the Renminbi Become a World Currency?" China Economic Review, vol. 20, no. 1, pp. 124-35.

Dominguez, Kathryn, and Jeffrey Frankel, 1993, Does Foreign Exchange Intervention Work? (Washington, DC: Institute for International Economics).

Dooley, Michael, J. Saul Lizondo, and Donald Mathieson, 1989, “The Currency Composition of Foreign Exchange Reserves," IMF Staff Papers, vol. 36, no. 2 (Washington, DC: International Monetary Fund, June); 
Eichengreen, Barry, 1992, Golden Fetters: The Gold Standard and the Great Depression, 1919-39 (New York: Oxford University Press).

Eichengreen, Barry. 2005. “Sterling’s Past, Dollar's Future: Historical Perspectives on Reserve Currency Competition,” NBER Working Paper No. 11336 (Cambridge, MA: National Bureau of Economic Research, May).

Eichengreen, Barry. 2010. "Managing a Multiple Reserve Currency World.” Paper prepared for the Asian Development Bank Institute/Earth Institute project on "Reform of the Global Monetary System" and in the project volume The 21st Century International Monetary System, edited by Jeffrey Sachs, Masahiro Kawai, Jong-Wha Lee, and Wing Thye Woo (Manila: Asian Development Bank). http://emlab.berkeley.edu/ eichengr/managing multiple_res_curr_world.pdf

Eichengreen, Barry, 2011a, Exorbitant Privilege: The Rise and Fall of the Dollar and the Future of the International Monetary System (Oxford: Oxford University Press).

Eichengreen, Barry. 2011b. "The Renminbi as an International Currency.” Journal of Policy Modeling 33 (5): 723-730.

Eichengreen, Barry, and Marc Flandreau. 2008. "The Rise and Fall of the Dollar, or When Did the Dollar Replace Sterling as the Leading Reserve Currency?" paper prepared for the conference in honor of Peter Temin, Cambridge, 9 May 2008. http://emlab.berkeley.edu/ eichengr/rise_fall_dollar_temin.pdf

Eichengreen, Barry, and Marc Flandreau, 2010, "The Federal Reserve, the Bank of England and the Rise of the Dollar as an International Currency, 1914-39,” BIS Working Paper No. 328, November.

Eichengreen, Barry, and Jeffrey Frankel, 1966, "The SDR, Reserve Currencies, and the Future of the International Monetary System," in M. Mussa, J. Boughton, and P. Isard, eds., The Future of the SDR in Light of Changes in the International Financial System (Washington, DC: International Monetary Fund);.

Eichengreen, Barry, and Donald Mathieson, 2001, "The Currency Composition of Foreign Exchange Reserves: Retrospect and Prospect," IMF Working Paper WP/00/131, Washington DC. Revised version in The Impact of EMU on Europe and the Developing Countries, edited by Charles Wyplosz (Oxford University Press), 2001.

Fingleton, Eamon, 1995, Blindside: Why Japan Is Still on Track to Overtake the U.S. by the Year 2000 (New York: Houghton Mifflin).

Frankel, Jeffrey, 1984, “The Yen/Dollar Agreement: Liberalizing Japanese Capital Markets,” Policy Analyses in International Economics No. 9, 1984;

Frankel, Jeffrey, 1992. “On the Dollar,” In The New Palgrave Dictionary of Money and Finance, MacMillan Press Reference Books, London.

Frankel, Jeffrey, 1995. "Still the Lingua Franca: The Exaggerated Death of the Dollar," Foreign Affairs, 74, no. 4, July/August, 9-16.

Frankel, Jeffrey, 2010, “The Renminbi Since 2005," in Simon Evenett, ed., The U.S.-Sino Currency Dispute: New Insights from Economics, Politics and Law (London: Centre for Economic Policy Research, April), pp. 51-60.

Frankel, Jeffrey. 2011. "Historical Precedents for Internationalization of the RMB," CGS/IIGG Working Paper (New York: Council on Foreign Relations), November. Along with http://www.cfr.org/thinktank/cgs/beijingpapers.html, at http://i.cfr.org/content/publications/attachments/CGS-IIGG_WorkingPaper17_Frankel.pdf

Fratzscher, Marcel, and Arnaud Mehl. 2011. "China's Dominance Hypothesis and the Emergence of a Tri-polar Global Currency System.” CEPR Discussion Paper No. 8671 (London: Centre for Economic Policy Research, 
November).

Frieden, Jeffry, 2000, "The Political Economy of The Euro as an International Currency." In The Euro as a Stabilizer in the International Economic System, edited by Robert Mundell and Armand Clesse (Boston: Kluwer Academic Publishers).

Funabashi, Yoichi, 1988, Managing the Dollar: From the Plaza to the Louvre (Washington, DC: Institute for International Economics).

Gao, Haihong and Yongdin Yu, 2011, "Internationalisation of the Renminbi," in Currency Internationalisation: Lessons from the Global Financial Crisis and Prospects for the Future in Asia and the Pacific, proceedings of BoK/BIS seminar on Currency Internationalisation, Seoul, March 19-20, 2009, BIS Papers No. 61 (Bank for International Settlements), December, pp. 105-124.

Genberg, Hans, 2009, “Currency Internationalisation: Analytical and Policy Issues,” Working Paper No. 31 (Hong Kong Institute for Monetary Research).

Goldberg, Linda. 2010. "Is the International Role of the Dollar Changing?" Current Issues in Economics and Finance 16 (1). http://www.newyorkfed.org/research/current_issues/ci16-1.pdf

Hale, David, 1995, “A Yen for Change: Why the Yen as a Reserve Currency is Not Far-fetched," International Economy, May/June).

Ito, Takatoshi, 2010, “China as Number One: How about the Renminbi?” Asian Economic Policy Review, vol. 5, no. 2, December, pp. 249-76;

Karmin, Craig, 2008, Biography of the Dollar (New York: Crown Business), pp. 110-16.

Kawai, Masahiro and Shinji Takagi, 2011, "The RMB as a Key International Currency: Lessons from the Japanese Experience," presented at the AEEF conference, Paris, January.

Kenen, Peter, 1983, The Role of the Dollar as an International Currency, Occasional Papers No. 13 (Group of Thirty, New York).

Kenen, Peter, 2011, "Currency Internationalisation," in Currency Internationalisation: Lessons from the Global Financial Crisis and Prospects for the Future in Asia and the Pacific, proceedings of Bank of Korea/BIS seminar on Currency Internationalisation, Seoul, March 19-20, 2009; BIS Papers No. 61 (Bank for International Settlements), December.

Kennedy, Paul, 1989, Rise and Fall of the Great Powers: Economic Change and Military Conflict from 1500 to 2000 (New York: Harper Collins).

Kindleberger, Charles, 1950, The Dollar Shortage (New York: John Wiley \& Sons and MIT Press).

Kindleberger, Charles, 1973, The World in Depression: 1929-1939 (Berkeley: University of California Press).

Kindleberger, Charles. 1981. International Money (London: George Allen \& Unwin).

Kindleberger, Charles, 1995, "Dollar Darkness,” The International Economy, May/June.

Krugman, Paul. 1984. "The International Role of the Dollar: Theory and Prospect.” In Exchange Rate Theory and Practice, edited by John Bilson and Richard Marston (Chicago: University of Chicago Press): 261-78.

Lee, Jong-Wha. 2010. “Will the Renminbi Emerge as an International Reserve Currency?” Paper presented at the workshop on "China Toward an Upper Middle-income Country: Challenges and Policy Options," organized by ADB and China Center for Economic Research (CCER) of Beijing University, 31 May - 1 June 2010. http://aric.adb.org/grs/papers/Lee.pdf . 
Li, D., and L. Liu, 2007, "RMB Internationalization: An Empirical Analysis," presentation at the Hong Kong Institute of Monetary Research Conference on Currency Internationalization, Hong Kong, October 15-16.

Lindert, Peter, 1969, "Key Currencies and Gold: 1900-1913," Princeton Studies in International Finance No.24, August, pp. 16-22.

Matsuyama, Kiminori; Nobuhiro Kiyotaki and Akihiko Matsui. 1993. "Toward A Theory of International Currency," Review of Economic Studies 60, April: 283-307.

McCauley, Robert. 2011. "The Internationalisation of the Renminbi." Speech to the Second Annual International conference on the Chinese Economy "Macroeconomic management in China." Hong Kong Institute for Monetary Research, Hong Kong SAR, 14 January.

McKinnon, Ronald, 1969, Private and Official International Money: The Case for the Dollar, Essays in International Finance, No. 74, Princeton University, April.

McKinnon, Ronald. 1979. Money in International Exchange (New York: Oxford University Press).

Matsuyama, Kiminori, Nobuhiro Kiyotaki, and Akihiko Matsui. 1993. "Toward A Theory of International Currency." Review of Economic Studies 60, April: 283-307.

Nurkse, Ragnar, 1944, International Currency Experience (Geneva: League of Nations).

Park, Yung Chul, and Chi-Young Song, 2010, "RMB Internationalization: Prospects and Implications for Economic Integration in East Asia," Asian Economic Papers, October.

Portes, Richard, and Helene Rey, 1998, "The Emergence of the Euro as an International Currency," NBER Working Paper No. 6424 (Cambridge, MA: National Bureau of Economic Research, February).

Prasad, Eswar and Shang-Jin Wei, 2007, "The Chinese Approach to Capital Inflows: Patterns and Possible Explanations," in Sebastian Edwards, ed., Capital Controls and Capital Flows in Emerging Economies: Policies, Practices and Consequences (Chicago: University of Chicago Press), pp. 421-80.

Prasad, Eswar, and Le (Sandy) Ye. 2012. The Renminbi's Role in the Global Monetary System (Washington, DC: Brookings). http://www.brookings.edu/reports/2012/02_renminbi_monetary_system_prasad.aspx

Ranjan, Rajiv, and Anand Prakash, 2010, "Internationalisation of Currency: The Case of the Indian Rupee and Chinese Renminbi." RBI Staff Studies 3/2010 (Reserve Bank of India, Department of Economic Analysis and Policy, April).

Rey, Helene, 2001, "International Trade and Currency Exchange," Review of Economic Studies 68, no. 2, April, 443-464.

Rogoff, Kenneth, 1998, "Blessing or Curse? Foreign and Underground Demand Euro Notes," Economic Policy, vol. 13, no. 26, April.

Schenk, Catherine, 2010, The Decline of Sterling: Managing the Retreat of an International Currency (Cambridge: Cambridge University Press).

Subramanian, Arvind. 2011a. "Renminbi Rules: The Conditional Imminence of the Reserve Currency Transition.” Working Paper Series No. 11-14 (Washington, D.C.: Peterson Institute for International Economics, September).

Subramanian, Arvind. 2011b. Eclipse: Living in the Shadow of China's Economic Dominance (Washington, DC: Peterson Institute for International Economics).

Swoboda, Alexander. 1969. "Vehicle Currencies in the Foreign Exchange Market: The Case of the Dollar." In 
R. Aliber, (ed.), The International Market for Foreign Exchange (New York: Praeger).

Takagi, Shinji, 2011, “Internationalizing the Yen, 1984-2003: Unfinished Agenda or Mission Impossible?" in Y. W. Cheung and G. Ma, eds., Asia and China in the Global Economy (Singapore: World Scientific Publishing). And in Currency Internationalisation: Lessons from the Global Financial Crisis and Prospects for the Future in Asia and the Pacific, proceedings of Bank of Korea/BIS seminar on Currency Internationalisation, Seoul, March 19-20, 2009; BIS Papers No. 61 (Bank for International Settlements), December, pp.75-92.

Tavlas, George, 1993, "The Deutsche Mark as an International Currency," in Dilip Das, ed., International Finance: Contemporary Issues (Routledge, London), 566-579.

Tavlas, George, and Yuzuru Ozeki. 1992. "The Internationalization of Currencies: An Appraisal of the Japanese Yen.” IMF Occasional Paper No. 90 (Washington, D.C.: IMF).

Triffin, Robert, 1960, Gold and the Dollar Crisis (New Haven, CT: Yale University Press).

Wu, Friederich, Rongfang Pan, Di Wang. 2010. "Renminbi's Potential to Become a Global Currency." China and the World Economy 18(1): 63-81. 


\section{Appendix: Measures of International Use of the RMB and Other Currencies}

Table A1: International Debt Securities — Currency Composition (2001-2011)

\begin{tabular}{|c|c|c|c|c|c|c|c|c|c|c|}
\hline \multirow{2}{*}{ Currency } & \multicolumn{2}{|c|}{ Average 2001 - 2005} & \multicolumn{2}{|c|}{ Average 2006 - 2010} & \multicolumn{2}{|c|}{2009} & \multicolumn{2}{|c|}{2010} & \multicolumn{2}{|c|}{2011 Q1 } \\
\hline & Levels & Shares & Levels & Shares & Levels & Shares & Levels & Shares & Levels & Shares \\
\hline Euro & $4,818.9$ & 42.2 & $11,210.0$ & 46.9 & $12,820.8$ & 47.5 & $12,173.6$ & 44.0 & $13,119.9$ & 45.2 \\
\hline US dollar & $4,703.3$ & 41.2 & $8,752.8$ & 36.6 & $9,745.2$ & 36.1 & $10,843.7$ & 39.2 & $11,128.9$ & 38.3 \\
\hline Pound sterling & 866.2 & 7.6 & $1,950.3$ & 8.2 & $2,241.4$ & 8.3 & $2,214.9$ & 8.0 & $2,275.7$ & 7.8 \\
\hline Japanese yen & 487.4 & 4.3 & 675.9 & 2.8 & 710.8 & 2.6 & 782.2 & 2.8 & 762.1 & 2.6 \\
\hline Swiss franc & 198.9 & 1.7 & 352.1 & 1.5 & 386.4 & 1.4 & 416.2 & 1.5 & 430.3 & 1.5 \\
\hline Canadian dollar & 89.4 & 0.8 & 271.0 & 1.1 & 307.7 & 1.1 & 354.1 & 1.3 & 369.2 & 1.3 \\
\hline Australian dollar & 92.9 & 0.8 & 253.2 & 1.1 & 276.5 & 1.0 & 335.6 & 1.2 & 350.9 & 1.2 \\
\hline Hong Kong dollar & 53.6 & 0.5 & 76.3 & 0.3 & 70.1 & 0.3 & 69.1 & 0.2 & 69.4 & 0.2 \\
\hline Swedish krona & 17.1 & 0.1 & 60.8 & 0.3 & 70.9 & 0.3 & 94.6 & 0.3 & 104.9 & 0.4 \\
\hline New Zealand dollar & 16.6 & 0.1 & 45.7 & 0.2 & 44.3 & 0.2 & 38.9 & 0.1 & 37.2 & 0.1 \\
\hline Norwegian krone & 19.1 & 0.2 & 41.1 & 0.2 & 54.5 & 0.2 & 65.1 & 0.2 & 75.0 & 0.3 \\
\hline South African rand & 10.7 & 0.1 & 32.3 & 0.1 & 37.9 & 0.1 & 35.8 & 0.1 & 35.5 & 0.1 \\
\hline Singapore dollar & 11.0 & 0.1 & 29.8 & 0.1 & 31.1 & 0.1 & 35.7 & 0.1 & 37.3 & 0.1 \\
\hline Brazilian real & 1.2 & 0.0 & 22.8 & 0.1 & 24.6 & 0.1 & 35.8 & 0.1 & 40.8 & 0.1 \\
\hline Mexican peso & 1.1 & 0.0 & 17.5 & 0.1 & 16.7 & 0.1 & 19.7 & 0.1 & 20.3 & 0.1 \\
\hline Czech koruna & 7.5 & 0.1 & 17.3 & 0.1 & 18.4 & 0.1 & 15.0 & 0.1 & 16.1 & 0.1 \\
\hline New Turkish lira & 1.3 & 0.0 & 16.2 & 0.1 & 16.6 & 0.1 & 19.7 & 0.1 & 19.7 & 0.1 \\
\hline Polish zloty & 5.6 & 0.0 & 13.3 & 0.1 & 14.5 & 0.1 & 14.9 & 0.1 & 14.6 & 0.1 \\
\hline UAE dirham & 0.0 & 0.0 & 12.2 & 0.1 & 19.6 & 0.1 & 19.7 & 0.1 & 20.4 & 0.1 \\
\hline Russian rouble & 0.4 & 0.0 & 11.7 & 0.0 & 14.4 & 0.1 & 16.1 & 0.1 & 19.9 & 0.1 \\
\hline Renminbi & 0.3 & 0.0 & 10.4 & 0.0 & 14.3 & 0.1 & 19.3 & 0.1 & 25.4 & 0.1 \\
\hline Danish krone & 7.3 & 0.1 & 6.9 & 0.0 & 5.4 & 0.0 & 4.5 & 0.0 & 3.8 & 0.0 \\
\hline Icelandic króna & 1.4 & 0.0 & 6.2 & 0.0 & 3.1 & 0.0 & 2.8 & 0.0 & 2.8 & 0.0 \\
\hline Malaysian ringgit & 0.2 & 0.0 & 3.9 & 0.0 & 4.9 & 0.0 & 6.8 & 0.0 & 7.1 & 0.0 \\
\hline Colombian peso & 0.4 & 0.0 & 3.8 & 0.0 & 4.2 & 0.0 & 5.4 & 0.0 & 6.6 & 0.0 \\
\hline Other currencies & 10.6 & 0.1 & 24.1 & 0.1 & 25.2 & 0.1 & 34.5 & 0.1 & 37.6 & 0.1 \\
\hline Total & $11,422.3$ & 100.0 & $23,917.6$ & 100.0 & $26,979.3$ & 100.0 & $27,673.7$ & 100.0 & $29,031.1$ & 100.0 \\
\hline
\end{tabular}

Note: 1) It includes international bonds and notes plus international money market instruments.

2) Levels in billions of US dollars; shares in percent of total.

3) Currency ranking is based on average $2006-2010$.

Source: BIS International Debt Securities Statistics, Tables 13A and 13B 
Table A2: Global Foreign Exchange Market Turnover — Currency Composition

\begin{tabular}{|c|c|c|c|c|c|c|c|c|}
\hline \multirow{2}{*}{ Currency } & \multicolumn{2}{|c|}{2001} & \multicolumn{2}{|c|}{2004} & \multicolumn{2}{|c|}{2007} & \multicolumn{2}{|c|}{2010} \\
\hline & Levels & Shares & Levels & Shares & Levels & Shares & Levels & Shares \\
\hline US dollar & 556.7 & 44.9 & 851.0 & 44.0 & $1,493.5$ & 44.9 & $1,689.0$ & 42.4 \\
\hline Euro & 234.9 & 19.0 & 361.8 & 18.7 & 630.1 & 19.0 & 777.6 & 19.5 \\
\hline Japanese yen & 145.8 & 11.8 & 201.4 & 10.4 & 391.1 & 11.8 & 377.7 & 9.5 \\
\hline Pound sterling & 80.8 & 6.5 & 159.5 & 8.2 & 216.8 & 6.5 & 256.3 & 6.4 \\
\hline Australian dollar & 26.8 & 2.2 & 58.2 & 3.0 & 71.9 & 2.2 & 150.9 & 3.8 \\
\hline Swiss franc & 37.0 & 3.0 & 58.3 & 3.0 & 99.4 & 3.0 & 126.7 & 3.2 \\
\hline Canadian dollar & 27.8 & 2.2 & 40.6 & 2.1 & 74.6 & 2.2 & 105.1 & 2.6 \\
\hline Hong Kong dollar & 13.9 & 1.1 & 17.0 & 0.9 & 37.2 & 1.1 & 47.0 & 1.2 \\
\hline Swedish krona & 15.5 & 1.2 & 21.2 & 1.1 & 41.5 & 1.2 & 43.6 & 1.1 \\
\hline New Zealand dollar & 3.4 & 0.3 & 10.3 & 0.5 & 9.2 & 0.3 & 31.7 & 0.8 \\
\hline Korean won & 5.0 & 0.4 & 11.0 & 0.6 & 13.4 & 0.4 & 30.1 & 0.8 \\
\hline Singapore dollar & 6.5 & 0.5 & 8.8 & 0.5 & 17.5 & 0.5 & 28.2 & 0.7 \\
\hline Norwegian krone & 9.0 & 0.7 & 13.3 & 0.7 & 24.2 & 0.7 & 26.3 & 0.7 \\
\hline Mexican peso & 5.1 & 0.4 & 10.7 & 0.6 & 13.8 & 0.4 & 25.0 & 0.6 \\
\hline Indian rupee & 1.4 & 0.1 & 3.1 & 0.2 & 3.8 & 0.1 & 18.9 & 0.5 \\
\hline Russian rouble & 2.1 & 0.2 & 6.1 & 0.3 & 5.7 & 0.2 & 17.9 & 0.5 \\
\hline Chinese renminbi & 0.0 & 0.0 & 0.9 & 0.0 & 0.1 & 0.0 & 17.1 & 0.4 \\
\hline Polish zloty & 2.8 & 0.2 & 3.6 & 0.2 & 7.5 & 0.2 & 16.0 & 0.4 \\
\hline Turkish new lira & 0.2 & 0.0 & 1.0 & 0.1 & 0.6 & 0.0 & 14.6 & 0.4 \\
\hline South African rand & 5.8 & 0.5 & 7.0 & 0.4 & 15.7 & 0.5 & 14.4 & 0.4 \\
\hline Brazilian real & 2.9 & 0.2 & 2.6 & 0.1 & 7.9 & 0.2 & 13.6 & 0.3 \\
\hline Danish krone & 7.4 & 0.6 & 8.4 & 0.4 & 19.8 & 0.6 & 11.3 & 0.3 \\
\hline Hungarian forint & 0.1 & 0.0 & 1.9 & 0.1 & 0.3 & 0.0 & 8.6 & 0.2 \\
\hline Malaysian ringgit & 0.5 & 0.0 & 0.5 & 0.0 & 1.2 & 0.0 & 5.5 & 0.1 \\
\hline Thai baht & 0.9 & 0.1 & 1.9 & 0.1 & 2.5 & 0.1 & 3.8 & 0.1 \\
\hline Other Currencies & 46.4 & 3.7 & 73.7 & 3.8 & 136.9 & 3.7 & 124.0 & 3.1 \\
\hline All currencies & 1,239 & 100 & 1,934 & 100 & 3,324 & 100 & 3,981 & 100 \\
\hline
\end{tabular}

Note: 1) Levels in billions of US dollars; shares in percentage of average daily turnover in April of each year.

2) Currency ranking based on average turnover for 2010.

Source: Bank of International Settlements, 2010 Triennial Central Bank Survey; IMF calculations. 
Table A3: Global Foreign Exchange Derivatives Market Turnover Currency Composition, 2010

\begin{tabular}{|c|c|c|c|c|c|c|c|c|c|c|}
\hline \multirow{2}{*}{ Currency } & \multicolumn{2}{|c|}{ Outright Forwards } & \multicolumn{2}{|c|}{$\begin{array}{l}\text { Foreign Exchange } \\
\text { Swaps }\end{array}$} & \multicolumn{2}{|c|}{ Currency Swaps } & \multicolumn{2}{|c|}{$\begin{array}{l}\text { Options and Other } \\
\text { instruments }\end{array}$} & \multicolumn{2}{|c|}{ Total } \\
\hline & Levels & Shares & Levels & Shares & Levels & Shares & Levels & Shares & Levels & Shares \\
\hline US dollar & 195.9 & 41.4 & 800.6 & 45.4 & 18.6 & 42.4 & 79.4 & 38.3 & 1094.5 & 44.0 \\
\hline Euro & 74.6 & 15.8 & 304.8 & 17.3 & 8.6 & 19.5 & 43.5 & 21.0 & 431.6 & 17.3 \\
\hline Australian dollar & 14.5 & 3.1 & 70.5 & 4.0 & 2.9 & 6.5 & 7.7 & 3.7 & 95.5 & 3.8 \\
\hline Swiss franc & 9.5 & 2.0 & 63.6 & 3.6 & 0.9 & 2.0 & 6.7 & 3.2 & 80.7 & 3.2 \\
\hline Canadian dollar & 13.1 & 2.8 & 48.5 & 2.8 & 1.5 & 3.4 & 3.0 & 1.5 & 66.2 & 2.7 \\
\hline Hong Kong dollar & 1.9 & 0.4 & 34.8 & 2.0 & 0.2 & 0.4 & 0.8 & 0.4 & 37.7 & 1.5 \\
\hline Swedish krona & 4.3 & 0.9 & 28.1 & 1.6 & 0.3 & 0.8 & 1.5 & 0.7 & 34.2 & 1.4 \\
\hline Norwegian krone & 3.1 & 0.6 & 15.8 & 0.9 & 0.3 & 0.7 & 0.9 & 0.5 & 20.1 & 0.8 \\
\hline Mexican peso & 2.7 & 0.6 & 11.9 & 0.7 & 0.2 & 0.4 & 1.1 & 0.6 & 15.9 & 0.6 \\
\hline Indian rupee & 6.8 & 1.4 & 3.4 & 0.2 & 0.0 & 0.0 & 1.9 & 0.9 & 12.1 & 0.5 \\
\hline Russian rouble & 1.1 & 0.2 & 7.1 & 0.4 & 0.1 & 0.2 & 0.5 & 0.3 & 8.9 & 0.4 \\
\hline Chinese renminbi & 7.1 & 1.5 & 3.4 & 0.2 & 0.0 & 0.1 & 2.5 & 1.2 & 13.1 & 0.5 \\
\hline Polish zloty & 1.8 & 0.4 & 9.5 & 0.5 & 0.1 & 0.2 & 1.0 & 0.5 & 12.5 & 0.5 \\
\hline Turkish new lira & 1.5 & 0.3 & 6.3 & 0.4 & 1.0 & 2.2 & 1.9 & 0.9 & 10.7 & 0.4 \\
\hline South African rand & 1.4 & 0.3 & 7.8 & 0.4 & 0.1 & 0.2 & 0.5 & 0.3 & 9.8 & 0.4 \\
\hline Brazilian real & 6.4 & 1.4 & 0.4 & 0.0 & 0.2 & 0.4 & 2.3 & 1.1 & 9.4 & 0.4 \\
\hline Danish krone & 1.4 & 0.3 & 7.3 & 0.4 & 0.1 & 0.1 & 0.1 & 0.0 & 8.9 & 0.4 \\
\hline
\end{tabular}

Note: 1) Levels in billions of US dollars; shares in percentage of average daily turnover in April 2010.

2) Currency ranking based on average daily global foreign exchange market turnover in April 2010.

Source: Bank of International Settlements, 2010 Triennial Central Bank Survey; IMF calculations.

Table A4: Countries Holding more than 5 percent of their Foreign Exchange Reserves in Each Currency

\begin{tabular}{|c|c|c|c|c|c|c|c|c|c|c|}
\hline & \multicolumn{2}{|c|}{ Average 2001 - 2005} & \multicolumn{2}{|c|}{ Average $2006-2010$} & \multicolumn{2}{|c|}{2009} & \multicolumn{2}{|c|}{2010} & \multicolumn{2}{|c|}{2011 Q1 } \\
\hline \multicolumn{11}{|l|}{ Currency } \\
\hline U.S. dollars & 114 & 97 & 120 & 95 & 120 & 94 & 118 & 94 & 120 & 96 \\
\hline Euro & 86 & 73 & 90 & 71 & 90 & 71 & 87 & 70 & 85 & 68 \\
\hline Swiss francs & 3 & 3 & 2 & 2 & 2 & 2 & 1 & 1 & 1 & 1 \\
\hline Other currencies & 22 & 19 & 38 & 30 & 45 & 35 & 55 & 44 & 56 & 45 \\
\hline \multirow[t]{2}{*}{ Memorandum } & \multicolumn{10}{|c|}{ Number of Countries Reporting Reserves } \\
\hline & 118 & 100 & 126 & 100 & 127 & 100 & 125 & 100 & 125 & 100 \\
\hline
\end{tabular}

Source: IMF. Currency Composition of Official Foreign Exchange Reserves (COFER) 
Table A5: Average Daily Foreign Exchange Spreads

between Spot Bid and Ask Quotations against the US Dollar in New York

(Percent of ask price quotation)

\begin{tabular}{|c|c|c|c|}
\hline Currency & 2001-2005 & 2006-2010 & 2011 \\
\hline Euro & 0.0288 & 0.0161 & 0.0036 \\
\hline Japanese yen & 0.0319 & 0.0130 & 0.0059 \\
\hline Danish krone & 0.0396 & 0.0193 & 0.0062 \\
\hline Hong Kong dollar & 0.0093 & 0.0115 & 0.0084 \\
\hline Canadian dollar & 0.0386 & 0.0230 & 0.0119 \\
\hline Pound sterling & 0.0254 & 0.0232 & 0.0141 \\
\hline Swiss franc & 0.0302 & 0.0173 & 0.0156 \\
\hline Australian dollar & 0.0574 & 0.0466 & 0.0159 \\
\hline Indian rupee & 0.0759 & 0.0670 & 0.0230 \\
\hline Chinese renminbi & 0.0206 & 0.0172 & 0.0276 \\
\hline Singapore dollar & 0.0435 & 0.0671 & 0.0409 \\
\hline Mexican peso & 0.0867 & 0.0716 & 0.0428 \\
\hline New Zealand dollar & 0.0968 & 0.0800 & 0.0482 \\
\hline Norwegian krone & 0.0519 & 0.0580 & 0.0492 \\
\hline Swedish krona & 0.0521 & 0.0546 & 0.0501 \\
\hline Malaysian ringgit & 0.0687 & 0.1105 & 0.0605 \\
\hline Turkish new lira & 0.6232 & 0.2355 & 0.0975 \\
\hline Brazilian Real & 0.0976 & 0.0859 & 0.0994 \\
\hline South African rand & 0.3151 & 0.3195 & 0.1020 \\
\hline Polish zloty & 0.1707 & 0.1977 & 0.1039 \\
\hline Hungarian forint & 0.2318 & 0.2729 & 0.1089 \\
\hline Thai baht & 0.1087 & 0.1938 & 0.1225 \\
\hline Korean won & 0.1118 & 0.1164 & 0.1558 \\
\hline Russian rouble & 0.1917 & 0.0790 & 0.2579 \\
\hline
\end{tabular}

Note: 1) Quotes shown reflect closing prices computed by Bloomberg as a composite of providers in New York.

2) Top 25 currencies based on average foreign exchange market turnover on April 2010. Currencies ranked based on average daily spreads for 2011.

3) Data shown through July 28, 2011.

Source: Bloomberg and IMF Calculations. 
Table A6: Over-The-Counter (OTC) Derivatives: Currency Composition, 2001 2010

\begin{tabular}{|c|c|c|c|c|c|c|c|c|}
\hline \multirow{2}{*}{ Currency 3/ } & \multicolumn{2}{|c|}{ Average 2001 - 2005} & \multicolumn{2}{|c|}{ Average 2006 - 2010} & \multicolumn{2}{|c|}{2009} & \multicolumn{2}{|c|}{2010} \\
\hline & Levels & Shares & Levels & Shares & Levels & Shares & Levels & Shares \\
\hline US dollar & $2,031.0$ & 37.4 & $6,439.1$ & 44.5 & $6,177.8$ & 38.4 & $7,149.3$ & 41.8 \\
\hline Euro & $2,222.3$ & 41.0 & $4,974.0$ & 34.3 & $6,504.5$ & 40.4 & $6,270.3$ & 36.7 \\
\hline Japanese yen & 460.4 & 8.5 & 986.3 & 6.8 & $1,112.9$ & 6.9 & $1,366.2$ & 8.0 \\
\hline Pound sterling & 311.1 & 5.7 & 979.0 & 6.8 & $1,179.2$ & 7.3 & $1,004.9$ & 5.9 \\
\hline Swiss franc & 79.2 & 1.5 & 167.6 & 1.2 & 177.1 & 1.1 & 292.2 & 1.7 \\
\hline Canadian dollar & 59.0 & 1.1 & 140.2 & 1.0 & 140.7 & 0.9 & 140.2 & 0.8 \\
\hline Australian dollar & 24.3 & 0.4 & 103.5 & 0.7 & 97.8 & 0.6 & 141.2 & 0.8 \\
\hline Swedish krona & 47.5 & 0.9 & 99.0 & 0.7 & 118.7 & 0.7 & 95.6 & 0.6 \\
\hline Norwegian krone & 7.2 & 0.1 & 19.3 & 0.1 & 13.6 & 0.1 & 13.9 & 0.1 \\
\hline Hong Kong dollar & 6.5 & 0.1 & 13.7 & 0.1 & 12.5 & 0.1 & 10.4 & 0.1 \\
\hline Danish krone & 6.6 & 0.1 & 12.5 & 0.1 & 14.0 & 0.1 & 14.9 & 0.1 \\
\hline New Zealand dollar & 0.2 & 0.0 & 3.5 & 0.0 & 4.9 & 0.0 & 3.6 & 0.0 \\
\hline Thai baht & 0.1 & 0.0 & 0.1 & 0.0 & 0.0 & 0.0 & 0.0 & 0.0 \\
\hline Other currencies & 169.1 & 3.1 & 547.5 & 3.8 & 535.8 & 3.3 & 588.0 & 3.4 \\
\hline Total & $5,424.5$ & 100.0 & $14,485.2$ & 100.0 & $16,089.5$ & 100.0 & $17,090.8$ & 100.0 \\
\hline
\end{tabular}

Note: 1) Gross market values of OTC foreign exchange and single currency interest rate derivatives. For OTC foreign exchange derivatives values were divided by two because two currencies are involved in each transaction.

2) Levels in billions of US dollars; shares in percentage of the total.

3) Currency ranking is based on average 2006 - 2010 for total international debt securities.

Source: BIS Semiannual OTC derivatives statistics at end-December 2010, Tables 20B and 21B

Figure A1: Composition of Foreign Exchange Reserves: 2001 and 2011

End 2001; total FX reserves: USD 1,936 billion

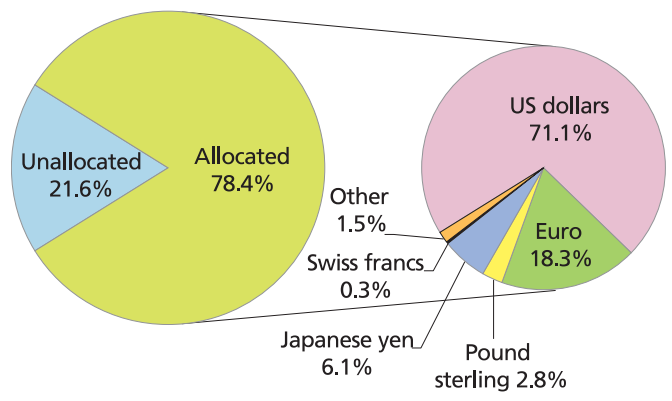

Note: Percent of total. Data for 2011 are for end-Q1.

Source: IMF. Currency Composition of Official Foreign Exchange Reserves (COFER)
End Q1 2011; total FX reserves: USD 9,694 billion

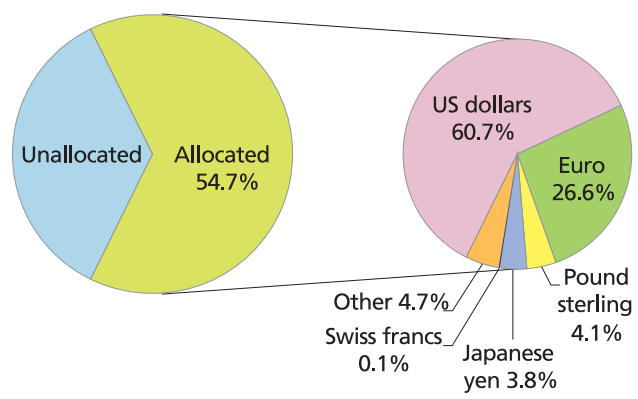


Figure A2: International Banking Liabilities — Currency Composition (2000 2011)

(percent of total)
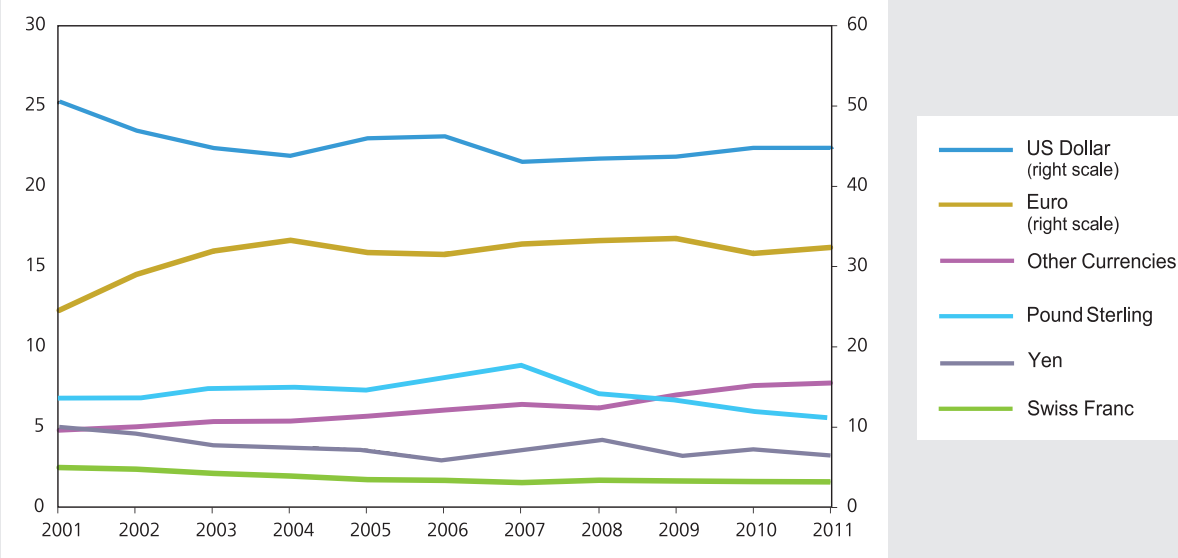

Note: Data for 2011 as of first quarter

Source: BIS International Locational Banking Statistics. Table 5A (Quarterly Survey) 